\title{
"Representatives of Their Own Choosing:" Practical Considerations in the Selection of Bargaining Representatives for Seasonal Farmworkers
}

\author{
Jeff L. Lewin $\dagger$
}

In this Article the author examines the present state of farm labor relations and suggests that federal preemption is the only viable means whereby effective regulation of agricultural labor relations may be obtained on a nationwide basis. The author argues that such federal control can best be obtained by encompassing agricultural workers within the National Labor Relations Act. The feasibility of this proposal is tested by drawing on NLRB precedents from other seasonal industries. Where the NLRA would not be suited to agriculture, amendments to the Act are proposed.

Agricultural employees have been excluded from coverage under the National Labor Relations Act [NLRA] ${ }^{1}$ since its passage in $1935,{ }^{2}$

$\dagger$ B.A. 1972, University of Michigan; J.D. 1975, Harvard University; Member of the Pennsylvania Bar.

This paper is dedicated to the memory of Bernard Dunau and the dreams of the farmworkers.

1. 29 U.S.C. $\$ \$ 151-68$ (1970).

2. The term "employee" in Section 2(3) of the NLRA does not include "any individual employed as an agricultural laborer." 29 U.S.C. \& 152(3) (1970). Although the bill originally submitted by Senator Wagner in 1934 would have included farmworkers, the draft that emerged froin the Senate Committee on J3ducation and Labor excluded "any individual employed as an agricultural laborer" from the definition of employee. S. 2926, 73d Cong., 2d Sess. (1934) (compare $\$ 3(3)$ at 1071, with 2(3) at 1085-86); National Labor Relations Board, Legislative History of the National Labor RELATIONS ACT 1935 (1949). The bill imtroduced in the following Congress continued the exclusion, the Committee Report explaining: "For administrative reasons the committee deemed it wise not to include under the bill agricultural laborers." Id. at 2306; S. REP. No. 573, 74th Cong., 1st Sess. (1934). These "administrative reasons" are not elaborated upon anywhere in the legislative history. The agricultural exclusion is generally explaimed as a concession by supporters of the Act to obtain the acquicscence of the farm block, which could have prevented passage of the bill. For a comprehensive analysis of the legislative history, see Morris, Agricultural Labor and National Labor Legislation, 54 CalIF. L. Rev. 1939, 1951-56 (1966). 
necessitating that the organization of farmworkers, a nationwide phenomenon, occur without the benefits of federal regulation. As a result, organization has taken place without the guarantee of elections or the supervision provided by the National Labor Relations Board [NLRB]. Consequently, unions such as the United Farni Workers [UFW] have been forced to rely on strikes and boycotts in their attempts to gain recognition by the growers. ${ }^{3}$ Such techniques have resulted in many labor disputes and extensive hitigation, while acconrphishnig only nrodest organizational success. ${ }^{4}$ Despite slow progress, however, farmworker unionization is becoming well established in various parts of the country, and it can no longer be argued that the ultimate success of agricultural unions depends upon federal labor legislation. The issue today is the legal framework within which the unionization of agriculture in the United States will be regulated. This Article asserts that-given the non-uniformity of state agricultural laws and the importance of the

3. J. Pitrone, Chavez: Man of the Migrants 148-49, 152-53 (1971). The UFW is not the only union actively seeking to represent farmworkers. In 1966 there was an unsuccessful melon strike by the Independent Workers Association in Starr County, Texas. Hearings on H.R. 5010 and Related Bills Before the Subcomm. on Agricultural Labor of the House Comm. on Education and Labor, 92d Cong., 1st Sess. 67 (1971) [hereinafter cited as Seminar on Farm Labor Problems-1971]. A union known as the Asociacion de Trabajadores Agricolas de Puerto Rico has recently been active in organizing Puerto Ricans housed in temporary labor camps in Delaware while performing seasonal farm labor. See, Asociacion de Trabajadores Agricolas de Puerto Rico v. Green Giant Co., 376 F. Supp. 357 (D. Del. 1974), affd, 518 F.2d 130 (3d Cir. 1975).

4. D. Pollitt, History of the Farm Labor Movement in the 20th Century, in Seminar on Farm Labor Problems-1971, supra note 3, at 57; U.S. BUREAU OF LABOR STATISTICS, DEp'T Of LABOR, LABOR UNIONISM IN AMERICAN Agriculture (Bull. No. 836, 1945) (the definitive work by Stuart Jamieson); Note, Agricultural Labor RelationsThe Other Farm Problem, 14 STAN. L. Rev. 120, 127, 137-40 (1961).

This Article assumes that inclusion of farmworkers within the NLRA would reduce the level of labor disputes and facilitate the unionization of farmworkers. Therefore, the discussion throughout is premised on the desirability of such unionization. Some commentators have suggested, however, that the chronic problems of farmworkers-low wages, unsafe and unhealthy working conditions, poor housing, child labor and exploitatiou by uuscrupulous labor contractors-can best be solved by specific legislation rather than by unions. Hearings on S.8 and S.1808 Before the Subcomm. on Labor of the Senate Comm. on Labor and Public Welfare, 91st Cong., 1st Sess. 61-91 (1969) (remarks of Charles Shunan, President, American Farm Bureau Federation) [hereinafter cited as Agricultural Labor Legislation-1969]. This suggestion, however, ignores the curreut labor disputes which seem to demand some form of administrative regulation.

Moreover, unions are becoming an essential part of today's farm labor picture. They will play an important role in the enforcement of protective legislation concerning wages and working conditions in addition to their direct influence through the collective bargaining process. Furthermore, agricultural unions may provide the only effective political voice and social community for people who are often transient and powerless visá-vis the dominant institutions of the society they feed. Hearings Before the Subcomm. on Migratory Labor of the Senate Comm. on Labor and Public Welfare, 91st Cong., 1st \& 2d Sess. 332-548 (1970) [hereinafter cited as Powerlessness-1970]. 
agricultural industry to the national welfare and economy-the present exclusion of agricultural employees from the NLRA is unwarranted. The Article also demonstrates that farm labor disputes could be handled efficiently by the present dispute-settling mechanisms of the NLRB.

Because of the vacuum created by the NLRA exclusion, the states have had primary responsibility for regulating agricultural labor relations. Nevertheless, of the 14 states with "little Wagner Acts," all but Hawaii and Wisconsin explicitly follow the federal policy of excluding agricultural workers from the definition of employees. ${ }^{5}$ But in 1972, Arizona, ${ }^{6}$ Idaho $^{7}$ and Kansas ${ }^{8}$ passed labor legislation directed solely at agricultural employment, and California has recently followed suit. ${ }^{\circ}$ The California statute, however, differs markedly froin the first group.

A cursory examination of the agricultural labor relations acts passed in Arizona, Idaho and Kansas reveals au unsyinpathetic or explicitly antagonistic attitude toward unionization of seasonal farmworkers. ${ }^{10}$ The new California act, on the other hand, is well tailored

5. Fuller, Farm Labor Relations, 8 IDAHo L. Rev. 66, 75 (1971).

6. 8 ARTZ. REv. STAT. ANN. §§ 23-1381 to -1395 (1972, Supp. 1975).

7. 5 IDAHO CODE $\S \S 22-4101$ to -4113 (1972, Supp. 1975).

8. 3A Kan. Stat. ANn. $\S 844-818$ to 830 (1973).

9. California Agricultural Labor Relations Act of 1975, CAL. LABor CODE $\$ \S$ 1140-66.3 (West Supp. 1976). For discussions of the new California act, see Levy, The Agricultural Labor Relations Act of 1975-La Esperanza De California Para El Futuro, 15 Santa Clara Lawyer 783 (1975); Comment, California's Attempt to End Farniworker Voicelessness: A Survey of the Agricultural Labor Relations Act of 1975, 7 PAC. L.J. 197 (1976).

The new California act, the most comprehensive state agricultural labor relations legislation to date, will be discussed throughout this Article. It must be noted, however, that the success of the act has been jeopardized by the failure of the California State Senate to provide funds to keep the state agricultural labor relations board operating. San Francisco Chronicle, Jan. 30, 1976, at 1, col. 5. This development illustrates the necessity of bringing agricultural labor relations within the provisions of the NLRA.

10. The electiou procedures in the Arizona Agricultural Employment Relations Act are not geared to seasonal employees-they require a preelection hearing followed by an electiou no sooner than 10 days thereafter. 8 Ariz. REv. STAT. ANN. $\$ 23-1389$ (Supp. 1975). More serious is the provisiou making it an unfair labor practice for a union "to call a strike unless a majority of the employees within the bargaining unit first approved the calling of such a strike by secret ballot." 8 ARIz. REv. STAT. ANN. § 23-1385(B) (13) (Supp. 1975). Furthermore, an employer is entitled to a 10-day injunction against any strike, conditioned on his submitting the dispute to compulsory arbitration. Id. § 23-1393(B). Thus, while the Arizona act bans the agricultural strike, only the grower is granted the right to seek binding arbitration.

The Idaho Agricultural Labor Act has no time limits on its preelection procedures. The Idaho act requires petition by 30 percent or more of the present employees and review by an agricultural board. Thus, a delay of at least a month from petition to election can be expected. Uuless seasonal workers are included in a unit with pernnanent workers who petition in advance of the harvest, they may be excluded from elections under the act. 5 IDAHO CODE $\$ \S 22-4101$ to -4114 (Supp, 1975). Although neutral on 
to the special problems of agricultural labor relations. Unfortunately, it is unlikely that other states will enact enlightened legislation similar to the California statute in the near future. For example, the states with the second and third largest seasonal farm labor forces, Texas and Florida, are right-to-work states ${ }^{11}$ and cannot be expected to enact balanced farm labor bills. Only federal legislative protection will suffice to achieve uniformity among the agricultural states ${ }^{12}$ while insuring a proper balance between management interests and the interests of farm laborers.

Federal regulation inay be effectuated in numerous ways. Rather than extend the NLRA to farmworkers, several Congressinen have proposed the enactment of a separate agricultural labor relations act. ${ }^{13}$ Proponents of such separate acts stress the uniqueness of agriculture and the inability of the NLRB to deal with agriculture's special problems. ${ }^{14}$ Behind this assertion, however, is usually a partisan interest in obtaining certain special provisions not found in the NLRA. ${ }^{15}$ Although

its face, the primary weakness of the Idaho act is its failure to take account of the technical problems concerning seasonal farmworkers.

The Kansas Agricultural Employment Act extends coverage to all those employing six or more workers for at least 20 days in 1 month and to other employers only if they so elect. 3A KAN. STAT. ANN. \$ 44-819(c) (1973). Since 90 percent of all farms employing permanent workers employed four or less, infra note 58, this means that there is little chance seasonal workers can ever vote in a harvest-time election, since they cannot petition for election until they have worked 20 days, and most harvests are shorter than 20 days. See text accompanying notes 53-60 infra. The Kansas act also makes it an unfair labor practice for employees "[t]o engage in a strike during periods of marketing of livestock or during a critical period of production or harvesting of crops or during mediation, fact-finding or arbitration proceedings ... ." 3A KAN. STAT. ANN. \$ 44828(7) (1973). Strikes are thus effectively precluded by these provisions. $\S 6$.

11. Vernon's Tex. Rev. Crv. Stat. ANN., art. 5207a (1971); Fla. Const. art. 1,

12. The current disuniformity is especially burdensome to migratory farmworkers. The most obvious victims are lettuce workers who migrate between California and Arizona. Uniform protection would be consistent with existing federal policy. Since agricultural labor disputes, both strikes and boycotts, have a nationwide inipact, the federal policy of avoiding industrial strife or unrest embodied in the NLRA would be served by uniform federal regulation of agricultural labor-management relations. In fact, one commentator has maintained that exclusion of farmworkers from the NLRA constitutes a violation of the equal protection clause of the Constitution. Note, The Constitutionality of the NLRA Farm Labor Exemption, 19 HAST. L.J. 384 (1968).

13. See, e.g., H.R. 8100, 93d Cong., 1st Sess. (1973) [Veysey]; H.R. 7513, 93d Cong., 1st Sess. (1973) [Talcott]; H.R. 4011, 93d Cong., 1st Sess. (1973) [LeggettQuie]. ,

14. Hearings on H.R. 881 (Title I), H.R. 4007, H.R. 4408 \& H.R. 7513 Before the Subcomm. on Agricultural Labor of the House Comm. on Education and Labor, 93d Cong., 1st Sess. 38 (remarks of Rep. Burt Talcott), $45-46$ (remarks of Rep. Albert Quie), 148 (prepared statement of Clifford G. McIntire, Legislative Director, and Matt Triggs, Assistant Legislative Director, American Farm Bureau) (1973) [hereinafter cited as Agricultural Labor-Management Relations-1973].

15. The Leggett-Quie Bill, H.R. 4011, 93d Cong., 1st Sess. (1973), forbids grow- 
some of their concerns may be valid, there is no reason why the provisions could not be included in amendments to the NLRA, ${ }^{10}$ thereby avoiding enactment of a separate agricultural act.

The assertion that the NLRB is unsuited to the task of administering labor law in the agriculture industry ignores the Board's vast experience with such seasonal industries as food processing, stevedoring, construction and lumber milling. ${ }^{17}$ A separate act would sacrifice this Board expertise while creating uncertainty to the extent that it declined to follow NLRB precedent. Creation of a separate act would also be less efficient than inclusion of agriculture under the NLRA. It would be difficult to justify the creation of a second nationwide administrative system where the caseload would be seasonal in many areas and minimal in others. Such constraints would either waste resources while the administrative board sat idle or necessitate regions so large as to impose hardship on parties involved in the proceedings.

A separate act would also create potential frictions at the interface between the two regulatory systems. Procedures would be required to resolve the jurisdictional boundaries of the two acts. ${ }^{18}$ For example, jurisdictional conflicts between a separate act and the NLRA could

ers from "knowingly" employing illegal aliens (\$ 8(a)(7)) and limits strikes and lockouts by allowing the parties to invoke a 40-day "cooling off" period for mediation leading to arbitration binding on the party invoking the procedures $(\$ 13(\mathrm{a})(2))$.

The Veysey Bill, H.R. 8100, 93d Cong., 1st Sess. (1973), provides for a 15-day "no strike, no lock-out" order, but without providing arbitration as compensation to the party against whom the order is obtained $(\S 17(a)(2))$. This bill also limits voting eligibility to workers employed at least 15 days during the preceding 45 calendar days or for at least 45 workdays during the preceding 120 calendar days $(\$ 3(b))$, thereby disenfranchising seasonal workers at short harvests.

The Talcott Bill, H.R. 7513, 93d Cong., 1st Sess. (1973), bans strikes and lockouts absolutely and restricts consumer boycotts even more severely than do the TaftHartley amendinents ( $\$ 101)$. It limits voting eligibility to workers employed for at least 14 days during the preceding 30 calendar days by a particular grower and 100 days in agriculture during the year $(\$ 3(6))$, thus disenfranchising 75 percent of all seasonal fannworkers.

The UFW has not submitted a proposal for a separate act, but opposes NLRA coverage unless agriculture is exempted from the Taft-Hartley restrictions on secondary activity and from section 14(b), which permits states to enact right to work laws. See Agricultural Labor Legislation-1969, note 4 supra, at 23 (prepared statement of Cesar Chavez).

16. Provisions allowing special treatment of the garment and construction industries are inade in National Labor Relations Act, 29 U.S.C. \$ $\$ 158(\mathrm{e}),(f)(1970)$.

17. Agricultural Labor Legislation-1969, supra note 4, at 248-56 (prepared statement of Ogden W. Fields, Executive Secretary, NLRB). Mr. Fields, setting forth the position of the NLRB, remarked that the Board is capable of dealing with the particular administrative problems in agriculture because of its expcrience in other seasonal industries.

18. California's Agricultural Labor Relations Board has been confronted with this issue and has deferred to the NLRB for resolution of particular cases. See Interharvest Inc., 1 A.L.R.B. No. 2 (Oct. 15, 1975). 
frustrate field and packing shed or cannery workers of a given grower if they wanted to participate in a single bargaining unit in cases where field workers noved to the packing sheds or canneries after the harvest. ${ }^{19}$ If a single union represented these workers both it and the einployer would be required to operate in accordance with the two regulatory systems. Uniformity between the systems in such a case would be unlikely, whereas a single act containing a limited number of special agricultural provisions would greatly reduce such uncertainty and confusion.

Finally, a strong political factor militates against creation of a separate act. Without the involvement of the countervailing force of organized labor, a separate board might easily be dominated by the agribusiness interests represented by the American Farm Bureau Federation. ${ }^{20}$ Because farmworker unions can be expected to lack the resources to conibat the agribusmess interests in Washington for many years to come, including farmworkers under the NLRA would at least guarantee them its basic protections.

If the NLRA is to effectively regulate farmworker umionization, specific amendnients should be considered. The special problems of agriculture must be treated specially by any regulatory act. This Article focuses on the problems likely to arise if attempts are made to apply NLRA practice and procedure to the agricultural labor force and proposes special administrative and legislative solutions to problems that might arise if the NLRA were expanded to include farm labor employees. Part I of this Article examines the characteristics of the agricultural work force, devoting special attention to the factors of migrancy and seasonality of farm employment. Part II then examines the techincal problems that would be created by application of the NLRA to the selection of bargaining representatives by agricultural workers. ${ }^{21}$

19. See e.g., Arena-Norton, Inc., 93 N.L.R.B. 375, $377-78$ (1951), in which the packing shed employees of several growers were deemed "agricultural laborers" because those workers were found to be primarily engaged in farming work and only incidentally involved with packing operations. For most of the growers, however, the packing shed employees constituted a separate and distinct work force, composed almost entirely of skilled migratory shed workers. A separate agricultural labor board would have jurisdiction over packing sheds and canneries which process only the produce of their owner's farm; the NLRB exercises jurisdiction wherever the produce of other farms is also handled. Garm Co., 148 N.L.R.B. 1499, 1501 (1964).

20. For a description of the Farm Bureau's operations, see S. BERger, Dollar HARVEST (1971), and note 24 supra. It is not surprising that one of the proposed acts would have its board chaired by an assistant secretary of agricnlture and would use regional offices of the Department of Agriculture as its own regional offices. H.R. 7513, 93d Cong., 1st Sess. (1973).

21. Those topics which have received most of the attention in recent congressional hearings on agricultural labor-management relations involve restrictions on harvest-time 


\section{Characteristics of the HIRED Farm Work Force}

\section{A. General Characteristics}

On the 2.7 million farms operating in 1972 there were only 2.7 million hired farmworkers, ${ }^{22}$ compared with over 3.2 million workers among the farm operators and their families. ${ }^{23}$ Of the 2.7 million hired workers, 1.1 million were "casuals" working less than 25 days per year, 918,000 were "seasonal" workers (25 to 149 days), 247,000 were "regular" workers (150 to 249 days) and 421,000 were "year-round" workers (250 days or more). ${ }^{24}$ Thus, it can be estimated that today casual and seasonal workers make up approximately three-fourths of the farm labor force but account for only 28 percent of the man-days worked. ${ }^{25}$ In the year of the survey, over 1.3 million of the workers-

strikes, exemption of agricultural unions from Taft-Hartley restrictions on secondary activity, and the creation of a new unfair labor practice to limit the availability of aliens as strikebreakers. Agricultural Labor-Management Relations-1973, supra note 14, at 123-26 (statement of Dolores Huerta); Hearings on H.R. 5010 (Title I) and Related Bills Before the Subcomm. on Agricultural Labor of the House Comm. on Education and Labor, 92d Cong., 2d Sess. (1972) [hereinafter cited as Agricultural Labor-Management Relations-1972]; Seminar on Farm Labor Problems-1971 supra note 3, at 53; Agricultural Labor Legislation-1969, supra note 4. Although these issues are both interesting and important, their resolution depends prinarily on factual and political considerations beyond the scope of this Article. Consequently, the subjects of strikes, boycotts and aliens will not be discussed except insofar as they are relevant to problems involving the selection of bargaining representatives.

22. U.S. Dep't of Agriculture, Agricultural Economic Report No. 265, THE HIRED Farm WorkING Force of 197314 (1974) [hereinafter cited as HFWF19731.

23. Economic Statistics Bureau of Washington, D.C., The Handbook of Basic ECONOMIC Statistics 65 (Jan. 1975) [hereinafter cited as HANDBOOK of BASIC ECONOMIC StaTISTICS].

24. HFWF-1973, supra note 22, at 14 . These figures on farmworker employment were derived from a 1973 study by the U.S. Department of Agriculture, which counted the total number of days worked by each farmworker without regard to how many days were worked for a particular employer. The Commerce Department's 1969 Census of Agriculture, by contrast, compiled separate statistics for permanent and temporary workers. 2 U.S. DeP'T of CoMmerce, Census of Agriculture, EQuipMENT, LABOR, EXPENDITURES, ChEMICALS 41-42 (1969) [hereinafter cited as 1969 CEnsus of Agriculture]. The census found 654,370 permanent workers, (defined as working 150 or more days for a single employer), down from 866,000 in 1964 . Id. at 41. A comparison with the 1973 USDA figures suggests that the number of permanent workers has continued to decline. By 1973 , there were only 668,000 farm workers employed for a total of 150 or more days, of whom 52,000 were migrants and many more were day-haulers working for more than a siugle farmer. $H F W F-1973$, supra note 22, at 14-15. A rough estimate would suggest that the true number of permanent workers in 1973 was closer to $1 / 2$ million, leaving approximately 150,000 non-migrant temporary workers who were employed for 150 days or more.

25. HFWF-1973, supra note 22 , at 14 . 
including almost 1 million students and nearly a quarter of a million housewives-were not in the labor force inost of the year. ${ }^{26}$ Over 400,000 additional farmworkers did non-farm work as their chief activity and used farm wagework to supplement their regular incomes. ${ }^{27}$ Currently, for example, many of the laborers work in canneries for several months after completing the annual harvest. These workers are not likely to be significantly concerned with umonization of agriculture, since their main pursuits are elsewhere. The 918,000 seasonal workers accounting for 24 percent of the man-days worked, ${ }^{28}$ however, would certainly be greatly affected by the extension of the NLRA to agriculture. Many could be expected to join agricultural unions, and their support would be crucial to the success of agricultural strikes.

The bulk of farm wagework is done by the regular and year-round workers who account for 20 percent and 52 percent, respectively, of the nan-days worked by hired farmworkers. ${ }^{29}$ These 668,000 people encompass most of those who are actively seeking unionization and include nuany simgle, full-time employees at moderately sized family farms. ${ }^{30}$ Most of these persons probably have inconies that place them at or below the poverty line.

Agricultural work is generally labelled "unskilled," since most of the necessary skills can be acquired within a few hours of on-the-job training. ${ }^{31}$ Compensation for harvest work is on a "piece-rate" basis, encouraging many farmworkers to specialize in the harvest of a particular crop in order to nuaximize their incomes by more efficient mastery of the few techniques involved. ${ }^{32}$ Although mechanization has gained an impressive foothold on fruit and vegetable farms, the need for large numbers of unskilled harvest-time workers will continue far into the future. ${ }^{33}$

26. Id. at 22 .

27. Id.

28. Id. at 14 .

29. Id.

30. The rough breakdown is 500,000 permanent workers and 150,000 temporary workers, of whom 50,000 are migrants. See note 24, supra. Approximately one-fourth of the permanent workers in 1969 were employed on farms with only one such worker. 1969 Census of Agriculture, supra note 24, ch. 4, at 41.

31. Agricultural Labor Legislation-1969, supra note 4, at 14 (statement of Dolores Huerta, viee-president, UFW).

32. Specialization among farmworkers is a well-known, but rarely documented, phenomenon. Both grapes and lettuce are harvested primarily by workers specializing in a single crop, which is one of the reasons why the groups that harvest them were among the first groups of farmworkers to be organized in the 1960's. As to specialization among peapickers, see Seminar on Farm Labor Problems-1971, supra note 3, at 63.

33. Fuller, A New Era for Farm Labor?, 6 IND. REL.: J. EcoN. \& Soc'y 285, 293 (1967). 


\section{B. Migrancy}

Much of the discussion about farmworkers has focused on the plight of the migrant worker. ${ }^{34}$ The Department of Agriculture defines "migratory worker" as anyone who at any time during the year travels to another county and stays overnight to do farm wagework. ${ }^{35}$ It is noteworthy, however, that the number of migratory workers is surprisingly small considering the attention they have received: there were only 203,000 such workers in 1973, comprising 8 percent of the farm work force and accounting for 8 percent of the man-days worked. ${ }^{80}$ This number represents a dramatic decline from the 276,000 estimated in $1967,{ }^{37}$ though it is unclear to what extent the decrease resulted from sampling variability. ${ }^{38}$ In addition, farmworkers who migrated were able to work more days than non-migrants. ${ }^{39}$

The employment pattern among migrants varies widely. Some travel alone or in small groups $s^{40}$ and inay wander from harvest to harvest according to no fixed pattern and without regular contact with a home base. Many spend a great portion of the year traveling in groups along three major migrant paths originating in California, Florida and Texas, ${ }^{41}$ generally traveling under the direction of a "crew leader" who finds them employment and accommodations, supplies transportation, and often serves as paymaster and supervisor. ${ }^{42}$ These crews, which may be as large as 150 or 200 persons, ${ }^{43}$ are found predominantly in the eastern and central states. ${ }^{44}$

34. Powerlessness-1970, supra note 4; SUBCOMM. ON MIGRatoRy LABOR OF THE Comm. on Labor and Public Welfare, The Migratory Farm Labor Prodlem in thb UnIted States, S. Rep. No. 83, 91st Cong., 1st Sess. (1969) [hereinafter cited as S. REP. No. 91-83-1969]; Hearings on S. 8, S. 195, S. 197, S. 198 Before the Subcomm. on Migratory Labor of the Senate Comm. on Labor and Public Welfare, 90th Cong., 1st Sess. (1967) [hereinafter cited as Migratory Labor Legislation-1967]; Hearings on S. 1864, S. 1865, S. 1866, 1867 Before the Subcomm. on Migratory Labor of the Senate Comm. on Labor and Public Welfare, 89th Cong., 1st \& 2d Sess. (1965-66) [hereinafter cited as Amending Migratory Labor Laws-1965-66]; and earlier hearings of this subcommittee going back to 1960 .

35. U.S. Dep't of Agriculture, Agricultural Handboor No. 365 (1969), reprinted in Powerlessness-1970, supra note 4, at 4521.

36. HFWF-1973, supra note 22 , at 14.

37. S. REP. No. 91-83-1969, supra note 34, at 4.

38. See HFWF-1973, supra note 22 , at 1 .

39. Id'. at 17.

40. G. Goodpaster, Scope of Public Regulation of Farm Labor Conditions, in Seminar on Farm Labor Problems-1971, supra note 3, at 3, 17-18.

41. S. REP. No. 91-83-1969, supra note 34, at 2-3.

42. Farm Labor Contractor Registration Act Amendments of 1975, S. REP. No. 1295, 93d Cong., 2d Sess. 2 (1974) [hereinafter cited as S. REP. No. 93-1295]; see note 40 supra.

43. Migratory Labor Legislation-1967, supra note 34, at 34 (statement of Frank A. Potter, Director, Office of Farm Labor Service, U.S. Dep't of Labor).

44. S. REP. No. 91-83-1969, supra note 34, at 3. 
A slightly different form of the crew leader, the "labor contractor," is prevalent in many areas, most notably California. The labor contractor does not liave a fixed contingent of workers, but instead acts as an agent of the growers in procuring workers at liarvest-tine. ${ }^{45}$ The labor contractor may find workers in other agricultural areas that are not in the midst of a harvest, in the barrios or shanty towns, or at the Mexican border. The literature is replete with stories of the abuses perpetrated by crew leaders and labor contractors, including transportation of workers in unsafe vehicles, withholding of earnings, discrimination in allocation of available work and rape by economic threat. ${ }^{46}$

While the number of migrants lias been declining, there has been an increase in the employinent of people who are technically not migrants because they return hoine each night instead of staying overniglit outside their lionie county. ${ }^{47}$ Often these persons must endure a 2-hour ride to and from work standing in an open truck. ${ }^{48}$ The labor contractors who supply workers on this sort of daily basis are called "dayhaulers", and it is said that day-haulers are responsible for some of the worst abuses in the labor contracting system. ${ }^{49}$ Not only are many nonmigrants entployed through day-haulers, but even among migrants 86 percent spend much of their time at some form of home base, ${ }^{50}$ during which time they often do day-haul work. ${ }^{\text {51 }}$

There are an estimated 5,000 crew leader/labor contractors engaged in interstate commerce and another 3,000 who procure workers only within a single state. ${ }^{52}$ Nearly all workers who are not permanently employed on a single farm probably have sonie contact with the crew leader or the labor contractor.

45. Hearings on S. 2070 \& S. 3202 Before the Subcomm. on Employment, Poverty, and Migratory Labor of the Senate Comm. on Labor and Public Welfare, 93d Cong., 2d Sess. 169 (1974) [hereinafter cited as FLCRA-1974].

46. Id. at 35 (statement of Barbara Rhine, attorney, UFW); $i d$. at 107-09 (statement of Luke Danielson, former investigator, Colorado Legal Services Agency); S. REP. No. 93-1295, supra note 42, at 2.

47. Hearings on H.R. 7597 Before the Subcomm. on Agricultural Labor of the House Comm. on Education and Labor, 93d Cong., 1st Sess. 175 (1973) (rentarks of Theodore Dietz, N.J. Dep't of Community Affairs) [hereinafter cited as FLCRA-1973]; Seminar on Farm Labor Problems-1971, supra note 3, at 39 (remarks of Rep. O'Hara and Rep. Veysey).

48. FLCRA-1974, supra note 45 , at $241,245,249-50$.

49. FLCRA-1973, supra note 47, at 63 (statement of Rev. James Vizzard, legislative representative, UFW), 94 (letter to the subcommittee from David Sweeney, political and legislative director, Teamsters Union).

50. S. REP. No. 91-83-1969, supra note 34 , at 35.

51. FLCRA-1973, supra note 47, at 63 (statement of Rev. Janies Vizzard, legislative representative, UFW); Seminar on Farm Labor Problems-1971, supra note 3 , at 39 (reniarks of Rep. O'Hara).

52. FLCRA-1973, supra note 47, at 107. 


\section{Seasonality of Employment}

Seasonality of employment is a major element in the life of farmworkers, especially for the harvesters of fruits and vegetables. ${ }^{53}$ In 1974 the estimated number of workers employed varied from a low of 688,000 in January to a high of $1,745,000$ in July. ${ }^{54}$ Harvest operations at a single farm generally last less than 2 months and are often as short as 2 weeks. ${ }^{55}$ At the extreme, melon and cherry harvests can be as short as 1 week and avocado and fig harvests only 5 days. ${ }^{56}$ Because of the brevity of the harvest periods, temporary workers who desire relatively continuous employment must constantly change employers, although in some instances a grower may have several crops that mature in succession. ${ }^{57} \mathrm{~A}$ non-migrant worker, however, can often secure relatively continuous employment simce differences in soil, irrigation and climate may enable a variety of crops to be grown on farms accessible to day-haul workers from a single area.

\section{Problems Raised by Agricultural Employment Patterns}

The $1 / 2$ million workers employed on a permanent basis by a single farmer should be inost suited to traditional umion organization on a "plant" or farm basis. These permanent workers have the most immediate imterest in wages, hours, working conditions, pensions and fringe benefits. Yet permanent workers are not at the forefront of current efforts at uniomization, because they are not generally subject to the abuses of the crew leader/labor contractor system, abuses which provide much of the incentive to unionization. Because permanent workers are employed in small numbers on single farms, ${ }^{58}$ their relationships with their employers are less impersonal and may even be similar to the ideal benevolent family farm suggested by opponents of agricultural unions.

Most of the pressure for unionization has come from seasonal harvest workers. But, whether migrant or not, these workers probably

53. S. ReP. No. 91-83-1969, supra note 34, at 7-8.

54. HaNdBoor of BASIC ECONOMIC STATISTICS, supra note 23, at 65.

55. Agricultural Labor-Management Relations-1973, supra note 14, at 50 (remarks of Rep. William Ford), 111 (prepared statement of Dolores Huerta, vice-president, UFW).

56. Id. at 151 (Rep. William Ford-cherries); Amending Migratory Labor Laws1965-66, supra note 34, at 202 (remarks of Russell Benedict, program consultant, National Advisory Committee on Farm Labor-avocados and figs). No general statistics are available. More precise figures would be extremely valuable in planning for expedited elections. See text accompanying notes 152-79 infra.

57. Agricultural Labor-Management Relations-1972, supra note 21 , at 50 (remarks of Rep. Ullman).

58. Over 90 percent of all farms reporting permanent workers employed four or less. 1969 Census of Agriculture, supra note 24, vol. 2, ch. 4, at 42. 
lack a continuing interest in the wages and working conditions on any given farm. The harvest at each farm is short, and workers do not necessarily return to the same farms each year. Hence, the concerns of seasonal workers are more specialized than are those of the permanent workers, because issues such as the harvest-time piece rate and temporary housing represent higher priorities than do issues such as hourly wages and paid vacations. Consequently, seasonal workers cannot rely on permanent workers to represent their interests adequately.

If seasonal workers inust organize their own union, however, they must overcome several barriers. For example, the short duration of their employment at each farm requires that the entire election process, from the collection of authorization cards to the conduct of an election, be either revised or telescoped into a harvest which may be as short as 2 weeks or less. ${ }^{59}$ Then in later harvests there nay be problems in conforming with rules concerning the scheduling of subsequent elections. The crew leader/labor contractor system poses additional problems relating to the selection of bargaining representatives. For many migrant workers the crew leader is, in effect, their employer. This suggests that the migrant crew would constitute an appropriate bargaining uunt which, in turn, could pose umique administrative challenges. But where, as is often the case, the labor contractor has no fixed crew of workers, it may be difficult to determine whether the labor contractor or the grower for whom the workers are procured should be considered the employer. Finally, the entire institution of crew leaders and labor contractors is potentially in conflict with the development of a union hiring hall.

The preceding discussion suggests some of the problems that would be encountered in any attempt to unionize farmworkers. Under the present NLRA exclusion, regulation is left to the states. This is not a satisfactory solution in view of the anti-union approach taken by a nuuber of states and the failure of most states to legislate in this area. Although the NLRA itself is not geared to the special problems of applying labor law to agriculture, amending the NLRA would be more practical than would be enacting special legislation to regulate agriculture. Part II discusses the technical challenge of applying the NLRA to agriculture. ${ }^{60}$

59. Some of these problems might be alleviated if elections were conducted on a multi-employer basis, but this suggestion raises sufficient additional problems to warrant separate consideration. See text accompanying notes 258-68 infra.

60. Hopefully, the suggestions for NLRA amendments will be equally valuable to any consideration of a separate federal bill regulating agricultural umonization and will aid the new California Agricultural Labor Relations Board under the California Agricultural Labor Relations Act of 1975, CAL. LABOR CODE $\$ \$ 1140-66.3$ (West Supp. 1976). 
II

\section{SELECTION OF BARGAINING REPRESENTATIVES FOR SEASONAL FARM WORKERS}

The seasonal nature of the agricultural labor force could create problems in the selection of bargaining representatives by farmworkers. Indeed, the exclusion of farm workers from the Wagner Act was purportedly "for administrative reasons." cerns both the NLRB's capability to deal with these administrative problems within the existing statutory framework and the nodifications that would be necessary to adapt the NLRA to the exigencies of seasonal agricultural enployment. At the core of the discussion is an examination of analogous NLRB precedent from other industries, which will show that the Board is sufficiently flexible and sensitive to the problems to resolve thein without statutory modification. Where Board precedent does not suggest an answer, however, statutory solutions will be proposed, drawing heavily upon the California Labor Relations Act.

The discussion begins with a consideration of the jurisdictional standards of the NLRA, the applicability of these standards to agribusiness and the value of possible alternative stanclards. The problenis of determining appropriate bargaining umits under the NLRA for farmworkers in different working environments are then examined, followed by consideration of both election procedures and alternatives to elections in hight of NLRA election requirements that are not entirely suited to the short-term work periods of the agricultural laborer. Finally, problenis that arise after an initial election are discussed, particularly the problenis associated with NLRA statutory provisions and with precedent concerning the election bar and contract bar rules and union security.

\section{A. Jurisdictional Standards and the Extent of NLRA Coverage}

\section{Agribusiness and the Myth of the Small Farm}

Opponents of unionization have argued that unions are incompatible with the ideal of the small family farm ${ }^{62}$ But although sniall farms are numerically significant, they contribute little to total agricultural production and employ few farmworkers. The 1969 Census of Agriculture found 2,730,250 farms in the United States, ${ }^{68}$ barely half of the 1950 figure of 5.4 million and far below the peak of 6.8 million farms in operation when the Wagner Act was signed in 1935. ${ }^{.4}$ Since the

61. See note 2 supra.

62. Note, Agricultural Labor Relations-The Other Farm Problem, 14 STAN. L. Rev. 120, 125 (1961).

63. 1969 CENSUS of AGRICULTURE, supra note 24, at 11.

64. Id. 
number of acres in cultivation remained relatively stable throughout this period, the drannatic decline in the number of farms reflects the consolidation of small farms into larger units. ${ }^{65}$ Over a million farms with yearly farm product sales of less than $\$ 2,500$ remain, ${ }^{66}$ and these small farms contributed less than a billion dollars to the nation's farm output, which totaled $\$ 45.5$ billion in 1969.67 In short, 37.7 percent of all farms accounted for less than 2.2 percent of farm sales. Their contribution was and is so minimal that these small farms are excluded from the majority of statistics presented in the census reports. The remainder of the statistics herein are therefore based solely on the $1,733,683$ "major" farms with sales in excess of $\$ 2,500 .{ }^{88}$

The increasing concentration of production has induced commentators to use the term "agribusimess" when referring to the large farm operations. $^{69}$ Bureau of Census statistics compiled for farms with sales in excess of $\$ 100,000$ suggest the extent of agribusiness domination. Denominated "Class 1a," these farms rose in number from 31,401 to 51,995 between 1964 and 1969, then representing 3.0 percent of the inajor farms. ${ }^{70}$ These few farms had sales totalling $\$ 15.3$ billion, 34.4 percent of all farm product sales by major farms in 1969. ${ }^{71}$ In addition to their economic importance, "Class $1 \mathrm{a}$ " farms accounted for 48 percent of expenditures by major farms on hired labor and 56 percent of expenditures by major farms on contract labor. ${ }^{72}$ These large agribusiness concerns, not the small family farms, are the target of union organizing efforts.

\section{The Extent of Coverage Under NLRB Jurisdictional Standards}

The NLRB has statutory authority over all private busmesses engaged in interstate commerce. The Supreme Court has broadly construed this statutory grant to include employers with operations in a single state so long as they buy or sell goods shipped in interstate commerce. $^{73}$ The Board, lowever, has established its own "jurisdictional yardsticks" to regulate its caseload by excluding employers whose interstate transactions are de minimis. Since 1958, the Board's stand-

65. Id. ch. 2, at 11. Average acreage per farm has more than doubled as the number of farms has declined over this period.

66. Id. ch. 1, at $v$.

67. Id.

68. Id. These are denominated "Class 1-5" farms.

69. See, e.g., S. REP. No. 93-1295, supra note 42, at 2.

70. 1969 CENSUS of AGRICULTURE, supra note 24, ch. 1 , at $v$.

71. Id.

72. Id.ch. 4 , at 89 .

73. Santa Cruz Fruit Packing Co. v. NLRB, 303 U.S. 453, 464-67 (1938). Cf. NLRB v. Jones \& Laughlin Steel Corp., 301 U.S. 1, 37 (1937), which was the first in a line of cases upholding increasingly broader exercises of NLRB jurisdiction. 
ard for non-retail establishments has required that $\$ 50,000$ of either sales or purchases occur in interstate commerce before the Board will exercise jurisdiction. ${ }^{74}$ Absent legislation or manifestations of congressional intent to the contrary, the Board might apply these standards to agriculture; several factors, however, would mitigate against such an automatic application of the standard. In addition to jurisdictional limits, the Board has consistently maintained that elections will not be directed or representatives certified in bargaining units composed of a single employee. ${ }^{75}$ Simce a family can often run a large mechanized farm with a single hired worker, the exclusion of single-einployee units would eliminate naany farms otherwise within the Board's jurisdiction.

\section{a. The Farms Covered}

There are no statistics available regarding farms with over $\$ 50,000$ in interstate sales. The best approximation is provided by the Census of Agriculture, which compiles separate statistics for "Class 1" farms laving total sales in excess of $\$ 40,000$, the bulk of which are probably in interstate commerce. Given both the recent inflation and the increasing number of large farms, the 1969 "Class 1" farms should roughly represent the farms that would be covered under the Board's jurisdictional standards.

There were 221,690 "Class 1" farms in 1969, up from 142,696 five years earlier. ${ }^{76}$ Although they constituted only 12.8 percent of major farms, these "Class 1" farms were responsible for $\$ 25.4$ billion or 57 percent of major farm product sales. ${ }^{77}$ Of these farms, only 65,702 had two or inore permanent employees and only 108,858 had two or more seasonal einployees. ${ }^{78}$ Assuming an overlap of farms with botll permanent and seasonal workers, these figures suggest that only about 150,000 farms would meet the NLRB's current jurisdictional limitation and coinply witl the policy requiring that more than one employee be involved in order to constitute an appropriate bargaining unit.

Realistically, organizational efforts at farms with only two permanent workers or less than five seasonal workers will be rare. When unreasonably sinall units are subtracted, there remain only 39,683 "Class 1" farms with three or more permanent workers and 55,463 with

74. Siemons Mailing Service, 122 N.L.R.B. 81 (1958).

75. See text accompanying notes 100-15 infra. Disco Fair Stores, Inc., 189 N.L.R.B. 456, 462 (1971); Luckenbach Steamship Co., 2 N.L.R.B. 181, 193 (1936). Single employees are protected under the NLRA and are entitled to bargain through a representative, but the Board will not certify a unit composed of a single employee.

76. 1969 CENsus of AgRiculture, supra note 24, ch. 1, at $\boldsymbol{v}$.

77. Id.

78. Id. ch. 4, at 45,60 . 
five or more seasonal workers. ${ }^{79}$ In the immediate future, union organization is most likely at the 18,929 farms with five or more permanent workers and the 31,640 farms with 10 or more seasonal workers. ${ }^{80}$ It is therefore apparent that very few of the nation's 2.7 million farms will be unionized.

\section{b. The Farmworkers Covered}

Estimates of the nunber of farmworkers that would be covered under the Board's jurisdictional standards are difficult to procure. The figures bandied about in congressional hearings are that 108,400 farms and 45 percent of the hired farm work force would be covered. ${ }^{81}$ These figures were apparently provided by the Departments of Agriculture and Labor, but their derivation is uncertain. It is unclear, for example, whether they take into account the large number of farms with only a single employee; and the figures certainly do not shed any hight on the number of workers on farms where unionization is likely. A very rough estimate derived from the Census of Agriculture suggests that NLRA coverage would have its greatest impact on 250,000 permanent workers employed by Class 1 farms with five or more such employees, and on the $1 / 2$ million individuals employed on farms with 10 or more seasonal workers. ${ }^{82}$

Application of the Board's present jurisdictional standard to agriculture would have two important qualitative effects. First, by using only a dollar standard, the Board would have jurisdiction over many highly inechanized farms einploying only a small number of permanent workers and few seasonal workers. ${ }^{83}$ Second, the Board standard would deny coverage to a large number of workers on farms with less than $\$ 50,000$ in interstate sales. The exclusion of over 1300 such farms with five or more permanent workers would be insignificant; inore troubling would be the exclusion of the more than 80,000 farms with 10 or more seasonal einployees yet less than $\$ 40,000$ in sales. Of the 9,226 farms hiring 50 or more seasonal workers, there were 3,523 with less than $\$ 40,000$ in sales, and 793 of these had sales of less than $\$ 10,000 .^{84}$ Under present jurisdictional yardsticks, the Board would leave thousands of farmworkers no means to effectuate the rights that would be granted to then by the NLRA.

79. $\quad$ Id.

80. Id.

81. S. REP. No. 91-83-1969, supra note 34, at 22.

82. Derived from figures in the 1969 CENSUS OF AGRicusture, supra note 24, ch. 4 , at 45,60 .

83. Of the 51,995 farms with sales of over $\$ 100,000$ in 1969 , only 14,184 hired five or more permanent workers and only 12,509 hired 10 or more seasonal workers. Id.

84. Id. at 60 . 


\section{Alternative Jurisdictional Standards}

Several of the proposed federal acts contain explicit jurisdictional standards differing from those employed by the NLRB. All three of the bills proposing a separate agricultural labor relations act adopt the test used to determine coverage under the Fair Labor Standards Act [FLSA] as a jurisdictional standard: 500 man-days of labor in any quarter during the preceding year. ${ }^{85}$ This standard is equivalent to seven full-time workers or 20 seasonal workers at a 25 -day harvest. The Department of Labor estimates this standard would cover approximately 495,000 farmworkers, far fewer than would be covered under the present NLRB standard. ${ }^{86}$ The 500 man-day per quarter jurisdictional standard leans toward coverage of farms with a large number of permanent workers. In fact, one of the bills proposing this test would almost entirely exclude seasonal workers through its definition of employees. ${ }^{87}$ Although there may be merit to a sclieme basing jurisdiction on the number of workers rather than on the size of the enterprise, the 500 man-day standard would exclude many laborers on smaller farms. A 200 man-day standard, on the other liand, would cover all farms with three permanent workers or eight seasonal workers at a 25-day harvest. Thus, the number of farms covered under: such a standard would be about 200,000 , compared with less than 55,000 under the 500 manday test. ${ }^{88}$

A second proposal, incorporated in a bill imtroduced in 1972, would extend coverage to all farms with more than 12 employees at any time during the year or over $\$ 10,000$ in labor costs. ${ }^{80}$ Apparently, this standard would extend coverage to 60 percent of farmworkers on less than 1 percent of all farms. ${ }^{00}$ The number of workers covered would exceed the number that would be covered under the Board's standard because a large number of farms have less than $\$ 50,000$ in sales but either carry more than $\$ 10,000$ in labor costs or use at least 12 employees. ${ }^{01}$ By eliminating large mechanized farms and substituting smaller

85. Note 13 supra. All of the bills introduced in the $92 \mathrm{~d}$ Congress are summarized and printed in SUbComm. on Agruculturar Labor of THE House COMM. ON EDucation and Labor, Summaries of Legislative Proposals Relatino to Labor-Management ReLATions in Agriculture, 92d Cong., 2d Sess. (1972) [hereinafter cited as SUMMARIES-1972].

86. SUMMARIES-1972, supra note 85 , at 3 .

87. H.R. 1689, 92d Cong., 1st Sess. $\$ 3(6)$ (1972) limits the term "employee" to those employed at a given farm for 14 of the previous 30 days and who did more than 100 days of farm work in the previous year.

88. Derived from figures in the 1969 CENsus of Agriculture, supra note 24, ch. 4 , at 45,60 .

89. H.R. 3625, 92d Cong., 1st Sess. $\S 1$ (197l). See Summarres-1972, supra note 85 , at 70 .

90. Summaries-1972, supra note 85, at 3.

91. See text accompanying note 84 supra. 
labor-intensive ones, this proposal would extend the unionization franchise while leaving the Board with jurisdiction over roughly 140,000 bargaining units, approximately the same number as are included under the Board's present non-retail jurisdictional yardstick. ${ }^{22}$

The two proposed alternative criteria would utilize a farm's employnent rather than the volume of its sales as a jurisdictional standard. The FLSA test-500 man-days per quater-would be too restrictive, especially as applied to seasonal employees. But if clianged from 500 to 200 man-days per quarter, the FLSA test would provide broad coverage of farm workers. The 10-employee test suggested by the second proposal would be functionally equivalent to the modified FLSA test, assuming a 20-day harvest. The alternative $\$ 10,000$ labor cost test envisioned by the second proposal would be equivalent to two or three permanent workers, again approximately the same as the 200 man-day version of the FLSA test. Either of these standards would be an improvement on the Board's current non-retail jurisdictional yardstick.

The advantages of these alternative standards do not, however, automatically imply that Congress should incorporate one of them in the legislation whereby the NLRA is extended to agriculture. The yardsticks are a Board creation, devised to limit its caseload. Consideration of the trends toward concentration and mechanization in agriculture suggests that the Board should not be bound by rigid statutory limits on its jurisdiction. In the absence of limitations written into the NLRA, the Board would remain capable of flexible response to changing employment patterns, free to expand its jurisdiction to the full extent permitted by the commerce clause. Congressional attitudes on this issue could be considered by the Board in light of the record developed in lrearings and floor debates.

\section{B. Bargaining Unit Determination}

Section 9 (b) of the NLRA directs that:

The Board shall decide in each case whether, in order to assure employees the fullest freedom in exercising the rights guaranteed by the Act, the unit appropriate for the purposes of collective bargaining shall be the einployer unit, craft unit, plant unit, or subdivision thereof. ${ }^{93}$

If the NLRA were extended to encompass farmworkers, the selection of an appropriate unit in agriculture would generally involve problems already faced by the National Labor Relations Board in other industries.

92. See text accompanying notes 76-78 supra.

93. 29 U.S.C. $\$ 159$ (b) (1970). 


\section{Separate Tracts of Land as a Single Unit}

Where several tracts of land were owned by the same grower, the initial question would be whether each tract constituted a separate unit for purposes of bargaining. The Board and the courts have grappled with the issue of noncontiguous, single-employer units in such diverse industries as insurance, ${ }^{94}$ retailing $^{95}$ and inanufacturing. ${ }^{90}$ Although the Board begins with a presumption in favor of the single-location unit, ${ }^{97}$ its decisions have been influenced by industry and employer characteristics. In manufacturing, NLRB decisions reflect the structure of supervision, the proximity of the separate facilities and the interchange of employees among them. ${ }^{98}$ Decisions from the retailing and insurance industries often emphasize the administrative unit, but evidence of independent labor relations policies at the individual locations may be controlling. ${ }^{99}$ In all cases the extent of organization is considered, but it nay not be the controlling factor in the Board's decision. ${ }^{100}$

In extending coverage to agriculture it would be both unnecessary and unwise for Congress to set any further limits on the Board's discretion in this area. Although the possibility of substantial movement of enployees between tracts suggests that a single location unit would often be inappropriate, the Board's experience in other industries would provide an adequate guide in individual cases. ${ }^{101}$

\section{Departmental and Craft Units}

A inore difficult question would be whether the unit should consist of all the employees on a farm or instead allow for the existence of departmental and craft units. Separate departmental units are often created for einployees whose work is distinct and physically separate

94. E.g., NLRB v. Metropolitan Life Ins. Co., 380 U.S. 438 (1965); see C. Summers \& H. WrLlington, Cases and MatrRials on LABor LAW 520-24 (1968).

95. E.g., Haag Drug Co., 169 N.L.R.B. 877 (1968); see C. Summers \& H. WeLLINGTON CASES AND Materials ON LABOR LAW 521 (1968).

96. E.g., Pittsburgh Plate Glass Co. v. NLRB, 313 U.S. 146, rehearing denied mem. sub nom. Crystal City Glass Workers v. NLRB, 313 U.S. 599 (1941).

97. Note 95 supra.

98. E.g., Dixie Belle Mills Inc., 139 N.L.R.B. 629 (1962).

99. Compare Purity Supreme Inc., 197 N.L.R.B. 915 (1972) (dismissing petition for a single-store unit), with Angeli's Super Valu, 197 N.L.R.B. 85 (1972) (directing election at a single store despite employer's contention that only a three-store unit was appropriate).

100. National Labor Relations Act $\S 9(c)(5), 29$ U.S.C. $\S 159(c)(5)$ (1970); NLRB v. Metropolitan Life Ins. Co., 380 U.S. 438, $441-42$ (1965).

101. The Board could also draw upon precedent under the California Labor Relations Act. California's Agricultural Labor Relations Board dealt with this issue in Egger \& Ghio Co., 1 A.L.R.B. No. 17 (Dec. 11, 1975), finding that two ranclies 10 miles apart were not noncontiguous and that even if they were, the employees shared a substantial community of interest. 
from the other employees, whereas craft units encompass groups of employees having specialized skills that justify their imclusion in a separate bargaining unit. ${ }^{102}$ The NLRA allows for the existence of both departmental and craft units, though the Board does not always clearly distinguish between the two entities. Examples of departmental units within a large retail store include salespersons, stockroom employees, cafeteria workers and clerical personnel. ${ }^{103}$ Craft units are generally composed of workers operating sensitive machinery or performing skilled tasks such as construction or repairs within a factory. ${ }^{104}$

The Board has accumulated a large body of precedent regarding the appropriateness of departmental units. In determining whether a department within an estabhishment should constitute a separate unit, the Board considers the request of the union, the bargaining history, the nature of the enuployer's labor policy, the physical proximity of the enuployees and their community of interest-imcluding similarity of skills, responsibilities, wages and working conditions. ${ }^{105}$ By these standards, operators of farm nuachinery could not appropriately be considered a departmental unit. The machine operators and field workers would be found to be engaged in an integrated operation under comnon supervision. ${ }^{106}$ Neither the skills nor the wages of nuachine operators would set them apart from the field workers, ${ }^{107}$ particularly not to the degree that salespersons, stockroom enuployees, cafeteria workers or clerical personnel are set apart from other workers at their places of eniploynent. Although there is some history of separate bargaining by nachine operators, recent contracts have included them in the same

102. See, e.g., General Motors Corp., 111 N.L.R.B. 1238 (1955), where a severance election was directed for tool and die shop workers even though they comprised only 22 percent of the employees of the existing production and maintenance unit. Craft units are explicitly authorized by section 9 (b) of the NLRA. Departmental units are authorized by the $\S 9$ (b) phrase "plant unit, or subdivision thereof." National Labor Relations Act $\$ 9$ (b), 29 U.S.C. $\$ 159$ (b) (1970).

103. Allied Stores of New York, Inc., 150 N.L.R.B. 799 (1965).

104. See, e.g., Mallimekrodt Chemical Works, 162 N.L.R.B. 387 (1966); In re Globe Machine \& Stamping Co., 3 N.L.R.B. 294 (1937).

The California Labor Relations Act explicitly forbids the formation of departmental or craft units by requiring that the bargaming unit be composed of all the agricultural employees on a farm. CAL. LABOR CODE $\$ 1156.2$ (West Supp. 1976).

105. See, e.g., Allied Stores of New York, Inc., 150 N.L.R.B. 799 (1965) (separate units); Maas Bros., Inc., 88 N.L.R.B. 129, 131-33 (1950) (separate units).

106. For a description of a mechanized lettuce harvest crew, see H. PADFIELD \& W. Martin, Farmers, Workers AND MAchines 57 (1965) [hereinafter cited as PadFIELD \& MARTIN]. The authors also discuss cotton and citrus fruit harvests.

107. Under a 1973 UFW grape contract, field workers received $\$ 2.40$ per hour compared with a $\$ 2.75$ hourly wage for irrigators and truck drivers. Agricultural LaborManagement Relations-1973, supra note 14, at 94. The tben current contract betwcen the Teamsters and Bud Antle, Inc. guaranteed lettuce workers an hourly wage of $\$ 2.78$ while tractor operators received from $\$ 2.65$ to $\$ 3.52$ per hour. Id. at $80-81$. 
units with field workers. ${ }^{108}$ One situation in which the NLRB would be likely to find a departmental unit appropriate would be where a grower operated a cannery or packing shed in addition to field operations. Relevant factors would be the degree of interchange between field and plant workers (sometimes considerable), ${ }^{100}$ similarities of wages and working conditions and the employer's hiring and labor policies.

The other workers the Board would be likely to place in a separate departmental unit are truck drivers who haul produce from the farm to a warehouse or processimg plant. They generally have different interests and duties and have little contact witl the field workers, factors which the Board lias held justify a separate unit. ${ }^{110}$ The Board no longer automatically grants a severance election to truck drivers, however, and it will retain them in the unit where they work in proximity with other workers with common pay, hours and supervision. ${ }^{111}$ Nevertheless, truck drivers commonly have separate representation at canneries, ${ }^{112}$ and a similar arrangement might be appiopriate im many agricultural units.

Of more immediate concern, lowever, is the question whether separate craft units would be recognized in agriculture. The definition of "craft" was set fortl by the Board in 1954:

[A] true craft unit consists of a distinct and homogeneous group of skilled journeymen craftsmen, working as such, together with their apprentices and/or helpers. To be a 'journeyman craftsman' an individual must have a kind and degree of skill which is normally acquired only by undergoing a substantial period of apprenticeship or comparable training. ${ }^{13}$

The Board has developed a substantial body of precedent in determining whether to order a self-determination or "Globe" election at the request of a group of employees purporting to be members of a distinct craft. ${ }^{114}$ Although there have been swings in its policy, the Board has recently been sympathetic to the interests favoring single plant-wide units and

108. Id.

109. See note 19 supra.

110. E.H. Koester Bakery Co., 136 N.L.R.B. 1006, 1011-12 (1962).

111. Kalamazoo Paper Box Corp., 136 N.L.R.B. 134 (1962).

112. E.g., Imperial Garden Growers, 91 N.L.R.B. 1034 (1950); Stokely Bros. \& Co., 15 N.L.R.B. 872, 879-81 (1939). In the latter case a self-determination election was directed among truck drivers.

113. American Potash \& Chemical Corp., 107 N.L.R.B. 1418, 1423 (1954). For example, in the grape harvest, workers who have a special skill at packing may perform only that job and never pick, but the pay of pickers in each sub-group of four or five workers will depend on their combined productivity.

114. E.g., E.I. DuPont de Nemours \& Co., 162 N.L.R.B. 413 (1966); In re Globe Machine \& Stamping Co., 3 N.L.R.B. 294 (1937). 
opposing craft severance. ${ }^{115}$ In 1966, the Board listed six factors it considered relevant in determining whether to order a craft severance election: (1) Whether or not the proposed unit consists of a distinct and homogeneous group of skilled craftsmen; (2) The history of collective bargaining of the employees sought and at the plant involved; (3) The extent to which the employees in the proposed unit have established and maintained their separate identity during the period of inclusion in a broader unit; (4) The history and pattern of collective bargaining in the industry involved; (5) The degree of integration of the employer's production processes; and (G) The qualification of the union seeking to "carve out" a separate unit. ${ }^{116}$

On the basis of these factors, it is unlikely that the Board would often approve craft severance elections in agricultural units. At the outset, no group of field workers could fairly be called a craft under the Board's standard. Among the manual workers, the separate tasks in the harvest are part of an integrated operation without clear skill gradations. Machine operators, the most clearly defined skill group in the fields, have no formal apprenticeship program. The Board generally has regarded the absence of an apprenticeship program to be a reason for not finding a given working unit to be a separate craft unit. ${ }^{117}$ In addition, because a grower probably would not require a fixed amount of experience in selecting machine operators, it is likely that the Board would find no true craft involved. ${ }^{118}$ Operation of farm machinery requires few special skills, most of which may be learned quickly, and is generally considered semi-skilled labor. ${ }^{119}$

Even if the machine operators were found to be a separate craft, the other factors considered by the Board would weigh against craft severance. In the short bargaining history among agricultural employees, separate umion organization activity by machine operators lias seldom occurred. In the 1960's the Teamsters did organize some units of machine operators, ${ }^{120}$ but in recent years the organization among field workers lias encoinpassed machine operators in the general unit. ${ }^{121}$

115. Mallinckrodt Chemical Works, 162 N.L.R.B. 387 (1966).

116. Id. at 397.

117. E.g., Ditto, Inc., 126 N.L.R.B. 135, 137-38 (1960); Hughes Aircraft Co., 115 N.L.R.B. 504, 506-07 (1956).

118. Id.

119. PADFIELD \& MARTIN, supra note 106, at 57. Although the authors refer to machine operators as skilled workers, they do so in relation to the unskilled field workers. Their description of the wages and status of these workers indicates that they are not skilled craftsmen in the same sense as are carpenters, for example.

120. The Teamsters often organized the farm's truck drivers and in some cases the operators of other farm machinery. See Englund v. Chavez, 8 Cal. 3d, 572, 578, 504 P.2d 457, 460, 105 Cal. Rptr. 521, 524 (1972).

121. See note 107 supra. 
There is httle evidence that the machine operators have maintained a "separate identity" within the broader unit. Moreover, the mechanized harvest is an integrated operation in which field workers and nuachine operators work as a crew, in close proximity. Under these circumstances, the Board would probably find that whatever separate interests machine operators may have are submerged in the broader community of interests they share with all the workers on the farm. ${ }^{122}$

Thus, if the NLRA were extended to encompass agriculture, there would be no justification for any restriction on the Board's discretion in establishing less than farm-wide units. Rarely would the Board approve separate craft units of nuachine operators to the detriment of field workers. Yet, there might be situations where packing shed workers or truck drivers would have sufficiently distinct interests to render separate representation appropriate. A restrictive rule, absolutely precluding departmental and craft units-as is true of the California Labor Relations $\mathrm{Act}^{123}$ — would therefore be undesirable.

\section{Permanent and Seasonal Workers \\ a. Coverage of Seasonal Workers}

Seasonal farmworkers are generally employed for only a few weeks by a particular grower and do not regularly return to the same farms each year. ${ }^{124}$ As a result, collective bargaining might seem to be mappropriate for such workers, since they may not "possess sufficient interest in employment conditions ${ }^{9125}$ on any particular farm.

In Wm. P. McDonald Corporation, ${ }^{12 \beta}$ however, the Board clearly stated that migratory and seasonal workers are not to be denied coverage under the NLRA:

The Employer is engaged in a seasonal industry, and its employees are almost exclusively, as a result, seasonal and even migratory. However, contrary to the contention of the Employer, the seasonal nature of their employment does not per se operate to deny them the right to the processes of collective bargaining. ${ }^{127}$

The Board's general standard in seasonal industries is that the workers possess sufficient interest in eniploynient conditions to warrant their inclusion in the unit where they "have a reasonable expectation of

122. Cf. Mallinckrodt Chemical Works, 162 N.L.R.B. 387, 399 (1966).

123. CAL. LABOR CODE $\$ 1156.2$ (West Supp. 1976).

124. Amending Migratory Labor Laws-1965-66, supra note 34, at 595 (remarks of Martin Zaninovich, Delano grape grower).

125. Baumer Foods, Inc., 190 N.L.R.B. 690 (1971); California Vegetable Concentrates, Inc., 137 N.I.R.B. 1779 (1962).

126. 83 N.L.R.B. 427 (1949).

127. 1d. at 430. See also Arena-Norton, Inc., 93 N.L.R.B. 375 (1951). 
substantial employment from year to year". ${ }^{128}$ Although in $W m$. $P$. McDonald 90 percent of the employees returned each year, the Board has not always required numerical evidence of reemployment. In approving an election at a cannery which in 5 years had hired 591 persons to maintain a work force of between 60 and 110, the Board held it sufficient that "the employer looks to the same reservoir of workers year after year to obtain the majority of its employees."129

If seasonal workers were to be covered by the NLRA, it would have to be on the basis of their being drawn from a common labor pool. Numerical evidence of reemployment among harvest workers is virtually non-existent, and, because the labor contractor often handles the payroll, ${ }^{130}$ neither the union nor the eniployer nuay be able to substantiate workers' reemployment claims in a given case. ${ }^{131}$ A common agricultural labor pool, on the other hand, can be shown in at least two situations: the neighboring labor pool and the crop specialists.

The clearest instance of a common agricultural labor pool is where a grower hires workers from the surrounding area. ${ }^{132}$ With the increasing prevalence of day-haul work in agriculture, seasonal farmworkers are often drawn from a relatively fixed labor market. For example, most lettuce workers in the Salinas Valley make their permanent homes in the area and constitute exactly the sort of labor pool required by the Board. ${ }^{133}$ Similar circumstances probably exist in other major agricultural valleys in Califorma and elsewhere, regardless of crop specialization.

The second type of labor pool is that provided by the workers who specialize in a particular crop, following the harvest from farm to farm..$^{134}$ Grape workers in California follow this pattern, beginning with the harvest in the Coachella Valley and then moving north to La-

128. Knapp-Sherrill Co., 201 N.L.R.B. 223 (1973), enforced sub nom. Knapp-Sherrill Co. v. NLRB, 488 F.2d 655 (5th Cir.), cert. denied, 419 U.S. 829 (1974); Baumer Foods, Inc., 190 N.L.R.B. 690 (1971); Farmers' Union Coop. Bus. Ass'n, 178 N.L.R.B. 336 (1969), enforced sub nom. NLRB v. Jackson Farmers, Inc., 432 F.2d 1042, 1044 (10th Cir. 1970), cert. denied, 401 U.S. 955 (1971).

129. Cain Canning Co., 81 N.L.R.B. 213 (1949). See cases cited at note 147 infra.

130. See note 42 supra.

131. There may be a statistically significant likelihood of reemployment if workers tend consistently to seek employment through the same labor contractor and if labor contractors generally supply workers to the saine growers each season. No such data is available, although there is some evidence that this pattern does occur. FLCRA1974, supra note 45, at 234 (remarks of Elijah Boone, Regional Director, Community Action Migrant Program, Immokalee, Fla.).

132. See text accompanying note 51 supra.

133. Interview with farmworker Gregorio Salas, in Boston, July 15, 1973.

134. See note 32 supra. 
mont-Arvin and finally to Delano. ${ }^{135}$ These specialists, who harvest fruits and vegatables, often organize along quasi-craft hines. Although this suggests the desirability of having a multi-employer unit composed of the growers of a particular crop, ${ }^{136}$ the Board has approved simgleemployer units in the Alaska salmon canneries where the workers were drawn from a general labor pool on the West Coast, and "the great majority of these workers returned season after season to work for one or another of these Companies." 137

Both the Board's broad dictum asserting that seasonal workers are not to be demied the right to collective bargaining and its practice of acceding to union requests for elections among seasonal workers suggest that harvest workers would rarely be denied an election just because they lacked a substantial likelihood of reemployment. As a matter of policy, even where numerical evidence was lacking and no common labor pool could be shown, the fact that workers were sufficiently interested in the conditions of their employment to petition for an election would properly be sufficient to satisfy the Board. Since seasonal farmworkers have been the dominant force behind the current organizational efforts, it would be a mistake to interfere legislatively with their coverage (as several of the existing and proposed acts would do) by requiring a minimunı number of days of employment before they can be considered the employees of a particular grower. ${ }^{138}$

\section{b. Permanent and Seasonal Workers in a Single Unit}

Although it is fairly certain that the NLRB would permit seasonal workers to participate in collective bargaining, an important additional question is whether permanent and seasonal workers would have a sufficient community of interest to warrant inclusion in the sane unit. Permanent workers liave a special interest in fringe benefits and vacations and in wages and working conditions during the off-season, when piece rates are not paid. The immediate concerns of seasonal workers, on the other hand, are piece rates, working conditions during the harvest and temporary housing supplied by the grower. Furthermore, seasonal workers often so outnumber permanent workers that the interests of permanent workers might be ignored in a cominon bargaining umit.

135. J. Dunne, Delano 15 (1967). infra.

136. For a discussion of multi-employer units, see text accompanying notes 258-68

137. Alaska Packers Ass'n, 7 N.L.R.B. 141, 146 (1938).

138. See, e.g., note 15 supra; Idaho Agricultural Labor Act of 1971 (which limited voting eligibility to those who had worked for at least 14 days prior to the elcction), ch. 174, \& 8(1), [1971] Idaho Sess. Laws 832 (expired 1972). The 14-day requirement was eliminated in the 1972 version of the Idaho act. IJAHO CODE $\$ 22-4109$ (Supp. 1975). 
Countervailing considerations, however, suggest the need for a single unit of permanent and seasonal workers. At harvest time both groups work together in an integrated operation. Thus, it is possible that differences in wages and working conditions would generate friction between thein, especially if the permanent workers were given the most desirable jobs. Separate units could also result in the creation of de facto craft units, which would severely limit the upward mobility of seasonal farmworkers, who already have few opportunities for advancement.

The more telling argument in favor of joint units is that permanent and seasonal workers do share a great commumity of interest. Seasonal workers, especially older ones, are concerned with the hourly wage; conversely, permanent employees, like the seasonals, are often paid by piece rate during the harvest. All workers share an interest in adequate rest periods, restrictions on pesticide usage, and the availability of fresh water and toilet facilities in the fields. Similarly, union security and the grievance procedure are nuatters of common concern. Unionadministered pension funds can benefit seasonal as well as permanent employees. ${ }^{139}$ Finally, a joint unit would have greater bargaining power: a strike by permanent workers alone would be futile, for even during pre-harvest operations they could be easily replaced; a strike by harvest workers would also be more effective if joined by the permanent workers who may occupy key positions.

The Board has wrestled with the problem of joining seasonal and permanent workers in a common unit since early in its history. ${ }^{140}$ Several factors are relevant to the question whether a sufficient community of interest exists to warrant inclusion of the two groups in a single unit. These include bargaining history, a coniparison of wages, hours, job classifications and duties, common supervision and unity of interests in fringe benefits. ${ }^{141}$ The fact that seasonal workers are paid on a piece rate basis is not controlling, ${ }^{142}$ nor is their exclusion fron fringe

139. Both the UFW and Teamster contracts currently provide for employer contributions to the union pension fund. Agricultural Labor-Management Relations-1973, supra note 14 , at $60-80$.

140. See, e.g., Stokely Bros. \& Co., 15 N.L.R.B. 872 (1939) (excluding seasonal workers, but allowing them to be separately represented at one plant); Old Mission Packing Corp., Ltd., 18 N.L.R.B. 953 (1939) (mcluding seasonal workers); James Vernor Co., 37 N.L.R.B. 388 (1941) (excluding seasonal workers). The Supreme Court, in NLRB v. Hearst Publications, Inc., 322 U.S. 111, 132-33 (1944), upheld the Board's discretion in determining an appropriate unit on the basis of tenure rather than on the basis of the function of employees.

141. Compare, e.g., The American Agricultural Chem. Co., 73 N.L.R.B. 105 (1947) (including seasonal employees), with United Foods, Inc., Dulaney Foods Division, 174 N.L.R.B. 91 (1969) (excluding "busy season" employees).

142. See, c.g., Wm. P. McDonald Corp., 83 N.L.R.B. 427, 436 (1949). 
benefits, ${ }^{143}$ nor is the fact that they vastly outnumber permanent workers, ${ }^{144}$ nor is bargaining history. ${ }^{145}$

Application of these criteria suggests that a combined umit would be appropriate in agriculture. In a recent line of cases dealing with the analogous problem in the food processing industry, however, the Board emphasized the likelihood of reemployment among seasonals, rather than a comparison of working conditions or methods of pay, as the determinate factor. ${ }^{146}$ But precedent from the food processing industry, where the season is usually 2 to 8 months long, may not be relevant to agriculture, where 2 months is practically the maximum duration for a simgle harvest. Nonetheless, there is ample case law to support either inclusion or exclusion of seasonal workers in most agricultural situations.

Despite the seeming inconclusiveness of: existing precedent, it should be noted that the Board generally assents to the wishes of the petitioning umion in deciding whether permanent and seasonal workers will be included in a simgle unit. ${ }^{147}$ Since the unit requested in the petition need only be an appropriate unit, rather than the most appropriate unit, the Board's tendency to comply with the umion's request is reasonable. So long as none of the unions involved requests separate units, permanent and seasonal workers should in nearly all cases be joimed in a single umit. When one umion requests a unit of permanent workers and another requests a joint umit, however, the Board is forced to make an independent determination. In one recent case, the Board granted seasonal workers a self-determination election to decide whether they would join an existing unit of permanent employees of a fruit processing plant, stating: "the seasonals share such a close community of interest with the year-round employees that they may be represented

143. E.g., California Vegetable Concentrates, Inc., 137 N.L.R.B. 1779 (1962).

144. E.g., Libby, McNeill \& Libby, Inc., 90 N.L.R.B. 279 (1950).

145. E.g., Millbrook, Inc., 204 N.L.R.B. 1148 (1973); California Vegetable Concentrates, Inc., 137 N.L.R.B. 1779 (1962).

146. Case-Swayne Co., 209 N.L.R.B. 1069 (1974); see also Millbrook, Inc., 204 N.L.R.B. 1148 (1973); Maine Sugar Indus., Inc., 169 N.L.R.B. 186 (1968) enforcement denied, N.L.R.B. v. Maine Sugar Indus., Inc., 425 F.2d 942 (1st Cir. 1970); California Vegetable Concentrates, Inc., 137 N.L.R.B. 1779 (1962).

147. N.L.R.B. v. Maine Sugar Indus., Inc., 425 F.2d 942, $946-47$ n.5 (1st Cir. 1970). In many cases, the Board has been satisfied with less than a 50 percent return rate, and in others the requirement was ignored. Bogus Basin Recreation Ass'n, 212 N.L.R.B. No. 122, (Aug. 12, 1974) (8 of 40 employees had been employed previously); Sebastopol Cooperative Cannery, 111 N.L.R.B. 530, 532 (1955) (only 183 of 421 employees returned froin previous year); Nephi Processing Plant, Inc., 107 N.L.R.B. 647, 649 (1953) (inore than 30 percent returned); Cain Canning Co., 81 N.L.R.B. 213 (1949) (hired 591 persons over 5 years to maintain a workforce of 60-110); J.M. Smucker Co., 75 N.L.R.B. 202 (1947) (no mention of reemployment); California Alinond Growers Exchange, 73 N.L.R.B. 1367 (1947) (no mention of reemployment). 
by the Petitioner only as part of its existing unit ..."148 On the other hand, it is possible that, in a different factual context, the Board would decide that the interests of the two groups so diverged that separate units were justified.

Board precedent suggests that if seasonal farmworkers were entitled to vote under the protection of the NLRA, they would often be included in a single unit with permanent workers. Rather than following the California provision, which requires that all workers nust be joined in a single unit, ${ }^{149}$ it would be best if the Board retained the power to order separate units or self-determination elections in situations where they would be appropriate. ${ }^{150}$ In the National Labor Relations Act, Congress has entrusted the Board with unreviewable discretion in the selection of appropriate bargaining units. ${ }^{151}$ Admittedly, the problems the Board would encounter in determining whether to join seasonal and permanent agricultural workers in a single unit, like those regarding craft units and noncontiguous lands, would be significant. But, since the Board has adequately dealt with equally difficult problenis in other industries, additional legislative guidance would be unnecessary.

\section{Choosing Representatives}

\section{Timing of Elections}

The lengthy NLRB election process would not be suited to the particular needs of seasonal farmworkers. The procedure begins when a union files a petition acconipanied by authorization cards signed by at least 30 percent of the current work force. ${ }^{152} \mathrm{~A}$ board representative then holds a hearing to determine whether a question of representation exists and to establish an appropriate bargaining unit. ${ }^{153}$ The coinbined requirements of a petition and a preelection hearmg would gener-

148. Millbrook, Inc., 204 N.L.R.B. 1148, 1149 (1973).

149. CaL. LaBor CoDe $\$ 1156.2$ (West Supp. 1976).

150. With the exception of the California Agricultural Labor Relations Act, none of the existing state statutes dictates that permanent and seasonal workers must always be in a single unit. Some states do not address the problem: Wis. STat. ANN. $\S \S$ 111.03-.19 (1974); HawaII REv. STaT. $\$ \$ 377-1$ to -18 (1968); IDaHo Code $\$ \S 22-4101$ to -4113 (Supp. 1975).

The Arizona Agricultural Employment Relations Act, ARIz. Rev. Stat. ANN. 231389(B) (Supp. 1975), grants the state agricultural labor relations board discretion to determine whether joint units are appropriate on a case-by-case basis. The Kansas Agricultural Employment Act, KAN. STAT. ANN. \& 44-823(e) (1973), mandates that the state board establish the largest unit consistent with effective administration, employees' community of interest, history of organization, geography, the effects of over-fragmentation, and the reconunendations of the parties involved.

151. Cf. American Federation of Labor v. NLRB, 308 U.S. 401 (1940); but see Leedom v. Kyne, 358 U.S. 184 (1958).

152. 29 C.F.R. \& 101.18 (a) (1974).

153. National Labor Relations Act \& 9(c), 29 U.S.C. $\$ 159$ (c) (1970). 
ally preclude farmworkers from both petitioning and voting during a single harvest season. Gathering the requisite number of signatures for the petition may take several days. More importantly, the average interval between the filing of the petition and the holding of an election ranges froin 30 days for consent elections ${ }^{154}$ to 75 days where questions are settled by the regional director and as many as 250 days where preelection questions are taken to the Board. ${ }^{155}$ Even a consent election might be impossible in a short harvest season, and an employer could always avoid an election by insisting that the regional director settle all preelection questions.

Where perinanent and seasonal workers were imcluded in a single unit, the current election procedures might not present as great a problem. In such situations, the permanent workers could file a petition several months in advance of the harvest, so that the hearing could be held and an election could be ordered well before the arrival of the seasonal workers. The Board has long held that only 30 percent of the current employees need to sign authorization cards, regardless of the eventual predicted employment. ${ }^{158}$ Elections in such cases are held at or near the seasonal peak, to assure voting by a representative number of employees. ${ }^{157}$

Advance petitioning by pernanent workers, however, would not always provide a solution to these procedural problems. The Board might find that pernnanent and seasonal workers should be in separate units. In other circumstances, it would be the seasonal workers, rather than the permanent workers, who would be actively seeking union representation. In either case, the seasonal workers would not have

154. In a consent election no hearing is held prior to the election; instead, the parties agree that any areas of dispute will be submitted to the regional director or the Board after the election has occurred. The procedures are set forth in 29 C.F.R. $\$ \$$ $101.19,102.62$ (1974).

155. Memorandum of confidential interview on file at the offices of the California Law Review.

156. Bordo Prod. Co., 117 N.L.R.B. 313 (1957); Sebastopol Cooperativc Cannery, 111 N.L.R.B. 530, 532 (1955).

The Idaho Agricultural Labor Act, IDAHo CoDe, § 22-4109 (Supp. 1975) permits a pre-harvest petition by permanent workers by providing that an election may follow a petition by 30 percent of "present employees," and requiring that a representative number of the workers in the unit be employed at the time of the election. The Kansas Agricultural Employment Act, KAN. STAT. ANN., \$ 44-323(d) (1973), on the other hand, provides that a petition for investigation or certification of an employee representative must be signed by " $30 \%$ of the employees within an appropriate unit," thereby precluding a petition before the seasonal workers have arrived.

157. Case-Swayne Co., 209 N.L.R.B. 1069, 1070 (1974). In Fruitvale Canning Co., 78 N.I.R.B. 152, 154 (1948), the Board ordered an election on the basis of authorization cards from 22 of 70 off-season employees. But the parties had agreed that the election should be held during the peak of the season when it was estimated that the number of employees would be more than 1300 . 
the benefit of an advance petition, and would be faced with the task of obtaining an election within the short period of the harvest. Finally, if the permanent and seasonal workers favored different unions, seasonal workers would have to be given an opportunity to gather signatures for an intervention petition. There are three possible solutions to the dilemma, two of which would require amendments to the NLRA.

\section{a. Election in the Subsequent Harvest}

Where the delay caused by the preelection hearing requirenient prevented an election from taking place during the harvest in which authorization cards were procured, the simplest course would be to hold the election during the subsequent seasonal peak. ${ }^{158}$ In the highly seasonal food processing industries, the Board has often found itself in the position of issuing the election order after the peak of employment has passed. In each case, the Board has ordered that the election be held at the next seasonal peak, at a time to be determined by the regional director. ${ }^{159}$ In one case, for example, an election was set for the next seasonal peak, which was nore than 6 nionths in the future. ${ }^{160}$ The Board explicitly rejected the employer's contention that inany of the cards had been signed by employees who would not be reeniployed the following season. Noting that 30 percent of the eniployees could reasonably have been expected to return, the Board added that the showing of interest is an administrative nratter not subject to attack. ${ }^{161}$ Two courts of appeals liave upheld the Board's practice on the grounds that the showing of interest is not a jurisdictional prerequisite to an election order. ${ }^{182}$

The use of authorization cards procured in year- 1 as a basis for an election in year-2 would be a reasonable solution to the problen of holding an election among seasonal workers in the face of a preelection hearing requirenent. The nuain drawback would be the inevitable delay prior to an election, which would inean that workers would not have a contract until sometime prior to the harvest in year-3.

\section{b. Pre-Harvest Petition}

One way to avoid the year-long delay between the petition and the election would be to allow a union to petition on behalf of seasonal

158. The Board currently follows this course instead of requiring a fresh showing of interest. Bogus Basin Recreation Ass'n, 212 N.L.R.B. No. 122 (Aug. 12, 1974).

159. See, e.g., California Vegetable Concentrates, Inc., 137 N.L.R.B. 1779 (1962).

160. Nephi Processing Plant, Inc., 107 N.L.R.B. 647 (1953).

161. Id. at 649.

162. NLRB v. White Constr. \& Eng'r Co., 204 F.2d 950, 953 (5th Cir. 1953); NLRB v. J.I. Case Co., 201 F.2d 597, 599 (9th Cir. 1953). 
workers in advance of the harvest without any signed authorization cards. The preelection hearing could be held and an election tentatively scheduled before the arrival of the seasonal workers, and the election could be conditioned on a showing of interest once the harvest had begun. In a pre-Taft-Hartley case, where the packing season lasted only 2 months, the Board utilized this procedure, explaining:

Inasmuch as the season is of limited duration, it is virtually impossible, during its short span, for a labor organization to file petitions, submit documentary proof of representation at or before a hearing, have the petitions fully processed in sufficient time for the holding of representative elections, and if certified, bargain collectively. Consequently, we entertained the petitions herein and conducted the hearing prior to the commenceinent of the melon packing season. ... Yet, we deen it essential that documentary evidence of substantial representation be presented before we conduct elections. ${ }^{183}$

But, not long after the passage of the Taft-Hartley amendments, the Board refused to accept a preseason petition in a similar case. Instead, it reverted to the standard practice of requiring a "showing among those currently employed in the unit at the time the petition was filed."104

The shift in the Board's position was apparently in response to the Taft-Hartley amendments to section 9(c) of the NLRA, which codified the requirement that the petitioner allege "that a substantial number of employees . . . wish to be represented ..."105 before the Board may act on the petition. Prior to passage of the amendments, the Board had been empowered to hold a hearing and order an election "whenever a question affecting commerce [arose] concerning the representation of einployees," $"$ and the Board had, on appropriate occasions, ignored the petition requirement (which was its own creation) and had found that a question of representation existed on the basis of a preseason petition. But, since the enactınent of the Taft-Hartley amendments, the Board has equated the 30 percent petition with "reasonable cause to behieve that a question of representation . . . exists." ${ }^{167}$ This interpretation is not clearly compelled by the statute. Nevertheless, given the position the Board has taken, an amendment to the NLRA would be needed to revive the practice of the preseason petition. An appropriate amendment would add the following proviso to section 9(c)(1): "Pro-

163. Arena-Norton Co., 62 N.L.R.B. 1070, 1073 (1945).

164. Holly Sugar Corp., 94 N.L.R.B. 1209, 1210 (1951) (emphasis in the original).

165. 29 U.S.C. $\$ 159$ (c)(1)(A) (1970); Holly Sugar Corp., 94 N.L.R.B. 1209 (1951).

166. National Labor Relations Act $\S 9$ (c), ch. 372, § 9(c), 49 Stat. 453 (1935), as amended 29 U.S.C. $\$ 159$ (c)(1)(A) (1970) (incorporating amendinents since 1935).

167. National Labor Relations Act § 9(c), 29 U.S.C. \$ 159(c) (1970). 
vided, that in a seasonal industry the Board nnay find that a question of representation exists and may issue an election order prior to the cominencement of the season, so long as the holding of the election is conditioned on the presentation prior to the election of proof that a substantial number of employees wish to be represented." Alternatively, the provision could be limited solely to agriculture, but pre-TaftHartley experience suggests that it could apply to all seasonal imdustries.

The suggested provision would be preferable to an election at the subsequent harvest, for the pre-harvest petition would eliminate the necessity of a 1-year delay between the petition and the election in a seasonal industry such as agriculture. The purpose of the petition requirement is to avoid holding an election when a union lacks substantial support among the employees. Given the high rate of turnover in seasonal industries such as agriculture, the use of petitions from the previous season could not imsure that there would be sufficient support for an election as effectively as would the conditional preseason petition. The advantages of allowing an immediate election among seasonal workers would outweigh the costs of unnecessary hearings in the few instances where elections were cancelled because the union was unable to prove its support. ${ }^{168}$

\section{c. Expedited Elections}

If pre-harvest petitions are deenied too costly or would render the election too susceptible to nanipulation by the employer, expedited election procedures would provide another alternative to the standard NLRB election procedure. The Board could coinpress the entire petition and election process into the span of a single harvest by dispensing with the preelection hearing and dealing with challenges to the scope of the appropriate unit and the eligibility of individual voters in a postelection hearing.

168. The Board could minimize the costs of unnecessary preseason hearings by adopting the following rule: "No union may file a preseason petition for a unit if, during the previous year, the union's preseason petition $\mathrm{m}$ that unit was cancelled for failure to provide a showing of sufficient support." The problem with such a rule would be that an employer, faced with an impending election, could, by discrimination in hiring, defeat the union or cause a cancellation of the election. The union would then be required to show evidence of section $8(a)(1)$ and (3) violations in order to preserve its right to an election. See 29 U.S.C. $\$ \S 158$ (a)(1), (3) (1970).

The California Labor Relations Act specifically makes it an unfair labor practice to "willfully . . . arrange for persons to become employees for the primary purpose of voting in elections." CAL. LABOR CODE $\$ 1154.6$ (West Supp. 1976); see M.V. Pista \& Co., 2 A.L.R.B. No. 8 (Jan. 14, 1976). The identical problein exists where an election is scheduled on the basis of a petition from the previous season, so the risk of election manipulation, by itself, would be no reason to reject the conditional pre-harvest petition. 
Postponement of the hearing until after the election was a common practice in seasonal industries before passage of the Taft-Hartley amendments. At such hearings board representatives reviewed problems of craft severance, voter eligibility and seasonal employees' imclusion in the unit $^{169}$-all crucial issues in agricultural elections. And in 1945, the Supreme Court upheld the use of post-election hearings, stating that they satisfied the requirements of the Wagner Act and the demands of due process. ${ }^{170}$ The Taft-Hartley amendments of 1947, however, implicitly forbade this practice, and section 9(c) of the NLRA now provides that a hearing "shall" be held in each case and an election directed only upon findings based on the record of the liearing. ${ }^{171}$

The prohibition of section 9 (c) is not absolute, however. The proviso to section $8(\mathrm{~b})(7)(\mathrm{C})$, added by the Landrum-Griffin Act, allows expedited elections without a prior hearing if an employer charges that a umon is engaging in prohibited recognitional picketing. ${ }^{172}$ The rationale underlying section $8(b)(7)(C)$ is the employer's need for a speedy resolution of the dispute and an end to the recognitional picketing, which can continue until the election is held. ${ }^{173}$ In Department \& Speciality Store Employees Union v. Brown, ${ }^{174}$ the Ninth Circuit Court of Appeals upheld the constitutionality of this proviso against a due process attack by a umion. The court found that a postelection hearing was sufficient to avoid a due process problem. ${ }^{175}$ For seasonal farmworkers, the prolonged election procedures could preclude exercise of the right to self-organization. Surely this would be a particularly compelling justification for dispensing with the preelection hearing.

To exempt agriculture (or seasonal industries generally) from the preelection liearing requirement would require an amendment to section 9(c) of the National Labor Relations Act. Unlike section 8(b)(7)(C) of the Act, which provides that when an employer demands an election, the election shall be directed "forthwith, without regard to the ... absence of a showing of substantial interest on the part of the labor

169. See, e.g., California Almond Growers Exch., 73 N.L.R.B. 1367 (1947). The Board explained its rationale for holding an election without a prior hearing as follows:

[W]e are of the opinion that, notwithstanding the existence of substantial issues, a prehearing election is especially well adapted for the selection of bargaining representatives in a seasonal industry where rapid changes in employment frequently require the holding of an immediate election.

Id., at 1371-72.

170. Inland Empire Dist. Council v. Millis, 325 U.S. 697, 708-10 (1945).

171. 29 U.S.C. § 159 (c) (1970).

172. 29 U.S.C. \& $158(\mathrm{~b})(7)$ (c) (1970).

173. Department \& Specialty Store Employees' Union v. Brown, 284 F.2d 619, 628 (9th Cir. 1960), cert. denied, 366 U.S. 934 (1961).

174. 284 F.2d 619 (9th Cir. 1960), cert. denied, 366 U.S. 934 (1961).

175. Id. at 628. 
organization,"176 the agricultural exemption should contain an explicit time frame for the procedure ${ }^{177}$ and should retain the requirement that the union make a showing of interest.

The California Labor Relations Act takes this course, requiring that an election be held within 7 days after the filing of the petition. ${ }^{178}$ Simce in some cases peak employment would last for more than a month, a 7-day requirement in the NLRA might not be necessary. It would be sufficient that an amendment instruct the regional director to act within 2 to 3 calendar days of the receipt of the petition and direct an election no more than 10 calendar days after the receipt of the petition. If the petition alleged that the peak season would last less than 14 days, an election within 5 to 7 days could be required. Such a procedure would require a significant but not unrealistic telescoping of the current procedures, which provide a minimum of 17 to 20 days between the direction of election and the balloting. Currently, an employer is given 7 days to furnish a list of eligible einployees, ${ }^{179}$ and the election is held no sooner than 10 days thereafter. ${ }^{180}$ Under expedited election procedures the list would be furnished within 48 hours of the direction of election. This would not pose substantial probleins for the employer so long as the union was required to give notice to the einployer simultaneously with its filing of the election petition. ${ }^{181}$

The 5 to 10 day framework, with a 30 percent petition requirement, would not present the Board with insurmountable administrative

176. 29 U.S.C. $\$ 158($ b) (7)(C) (1970). The "expedited" election in Department \& Specialty Store Employees' Union v. Brown, 284 F.2d 619 (9th Cir. 1960), cert. denied, 366 U.S. 934 (1961), was held a month after the petition was filed.

177. Section 377-5(d) of the Hawaii Employment Relation Act, HawaII Rev. STat. \$ 377-5(d) (1968), and section 111.05(4) of the Wisconsin Employment Peace Act, WIs. STAT. ANN. § $111.05(4)(1974)$ are similar to section $8(b)(7)(C), 29$ U.S.C. $\$$ $158(b)(7)(C)(1970)$, in that they contain identical provisions that "where it appears by the petition that [any] emergency exists requiring prompt action" the election shall be held "within such time as will meet the requirements of the emergency presented."

178. CaL. LABOR CODE $\S 1156.3$ (a) (West Supp. 1976).

179. Excelsior Underwear, Inc., 156 N.L.R.B. 1236, 1240 n.5 (1966).

180. NLRB Field Mauual $\S 11302-1$, cited in C. MORRIS, The DeVEloping LABOR LAW, 183-84 (1971).

181. The eligibility list might not need to include the addresses of the workers, since the union would generally not attempt to reach workers in their homes during the few days between the receipt of the eligibility list and the loolding of an election. The California Labor Relations Act, however, does require that the eligibility list include the workers' addresses. CAL. LABOR CODE $\$ 1157.3$ (West Supp. 1976). The California Agricultural Labor Relations Board has recognized that "an agricultural employer with a casual work force may experience greater difficulty than the typical industrial enployer in obtaining the necessary information" and imposes a standard of "due diligence." Yoder Brothers, Inc., 2 A.L.R.B. No. 4 (Jan. 7, 1976) (where the Board pointed out that this information could be obtained from the labor contractors). 
difficulties. ${ }^{182}$ Unions could be required to give advance notice to the regional director of an intention to file a petition. In any case, the Board would be able to anticipate election requests with reasonable accuracy.

An amendment to section 9(c) of the NLRA to allow for expedited elections could read as follows: "Provided, that in a seasonal industry the petition may request an expedited election, in which case the Regional Director must act upon the petition within three calendar days, any election directed must be held within ten days of the receipt of the petition, and the necessary hearing shall be conducted at a time after the election has been held."

\section{Alternatives to Elections: Pre-Hire Agreements and Recognitional Strikes}

Amendments providing for preseason petilions or expedited elections would probably be sufficient to guarantee representative elections for a majority of the farnworkers covered by the NLRA. Nevertheless, even expedited elections might not be possible where the harvest lasted less than a week. Alternatives obviating the need for elections altogether would include pre-hire agreentents and recognilional strikes.

\section{a. Pre-Hire Agreements}

One of the earliest proposals for extending NLRA coverage to farmworkers contained a provision that would have made section 8(f) applicable to agriculture. ${ }^{183}$ Currently applicable only in the building and construction industry, section 8(f) permits an employer and a union to bargain collectively without a demonstration by the umion that it represents a majority of the eniployees in the unit. ${ }^{184}$ The rationale underlying this provision is that the intermittent nature of employment in the construction imdustry would create administrative difficulties if an election were held at each construction site.

Proponents of extending section $8(f)$ to agriculture point to the similarities between employment patterns in agriculture and construction-seasonal employment of short duration, with few workers perma-

182. Due to the volume of its workload, the California's Agricultural Labor Relations Board has not always been able to hold an election within the 7-day period required by the California Labor Relations Act. Waller Flower Seed Company, 1 A.L.R.B. No. 27 (Dec. 30, 1975). In such cases the election is set aside only if prejudice to the parties is shown. Compare Ace Tomato Co., Inc., 2 A.L.R.B. No. 20 (Jan, 22,1976 ) (election set aside due to low turnout), with Klein Ranch, 1 A.L.R.B. No. 18 (Dec. 11, 1975) (election certified).

183. S. 1128, 87th Cong., 1st Sess, $\S 2$ (1961). This provision was included in bills introduced throughout the 1960's. See e.g., S. 8, 91st Cong., 1st Sess. § 2 (1969).

184. 29 U.S.C. $\$ 158(f)(1970)$. 
nently employed by a single employer. ${ }^{185}$ Such comparisons, however, ignore crucial distinctions between the extent of organization in the construction industry in 1959 and the extent of organization in agriculture today. The construction industry had a history of successful unionization predating the Wagner Act and was organized without resort to the NLRA election procedures. Until the Taft-Hartley Act evinced congressional intent to regulate unfair labor practices common to the building trades, ${ }^{186}$ the NLRB had declined to assert jurisdiction over the construction industry. When it became clear that coverage would have to be extended to the construction industry, the Board's general counsel drew up elaborate plans to hold elections in up to 700 localities to select area-wide representatives in each of the building trades. ${ }^{187}$ Overwhelming administrative obstacles, coupled with a lack of cooperation from the parties involved, kept these plans from reaching fruition. ${ }^{188}$ When section $8(f)$ was enacted in 1959 , it was still true that only a "minute percentage" of the unions in the building and construction industry had been certified in Board elections. ${ }^{189}$ In general, each craft in a locality had a separate local union, and occasional jurisdictional disputes arose over which craft local would be assigned to a given task. ${ }^{190}$ To have required elections under such circumstances would simply have ratified the position of the existing umions.

Unlike the tradition of unionization in the building and construction industry, successful union organization is a relatively recent phenomenon in agriculture. There is a long history of organizational campaigns in agriculture, but each campaign met with limited success prior to the 1960 's. ${ }^{191}$ Because agricultural labor is generally unskilled, agricultural unions could never acquire a monopoly through limited apprenticeship programs. The current conflict between the UFW and

185. See S. REP. No. $91-83-1969$, supra note 34 , at 21 ; see text accompanying notes 22-33, supra.

186. Plumbing Contractors Ass'n Inc., 93 N.L.R.B. 1081, 1084-85 (1951). This was the first instance in which the Board asserted jurisdiction in a representation case in the building and construction industry involving employees in an area-wide craft union rather than employees at a single construction site.

187. Address by R. Denham, NLRB General Counsel, Taft Act's Impact on the Construction Industry, before Associated General Contractors, February 11, 1948, in 21 L.R.R.M. 44, 48-50 (1948).

188. Note, Special Labor Problems in the Construction Industry, 10 STaN. L. Rev. 525,540 (1957).

189. Quinn, Pre-Hire Problems in the Construction Industry, 48 Geo. L.J. 380 (1959). But see, e.g., Denver Heating, Piping and Air Conditioning Contractors Ass'n, 99 N.L.R.B. 251 (1952); Plumbing and Heating Contractors Ass'n, 93 N.L.R.B. 1099 (1951); Plumbing Contractors Ass'n Inc., 93 N.L.R.B. 1081 (1951).

190. Note, Special Labor Problems in the Construction Industry, 10 STAN. L. Rev. 525,541 (1957).

191. See note 4 supra. 
the Teamsters, unlike local craft disputes in the construction industry, is not occurring at the interface of two defined craft union constituencies; it is, more correctly, a question of representation-a dispute as to which union will represent all the workers on a given farm. Elections in agriculture are needed not to ratify the status quo, but to establish representation rights witliout resort to strikes and boycotts.

Pre-hire agreenents would be no substitute for elections in agriculture. ${ }^{192}$ To allow a grower and a umion to sign a pre-lire contract where nore than o11e union sought to represent farmworkers would be to mvite the signing of "sweetheart" contracts with the least threatening union. Although the proviso to section $8(\mathrm{f})$ prevents the pre-hire agreenient from constituting a bar to an election petition, in practice sucli an election might be of little benefit. Once a pre-hire agreement had been signed, the uniou and the eniployer would be in control of the hiring process and could insure that those subsequently employed would ratify the incumbent union. This danger is dramatically illustrated by a case from the Alaska salmon industry, where two unions petitioned for an election amo11g seasonal cannery workers, but the eniployer signed a pre-hire agreement with a third union calling for a union hiring lall, thus insuring a subsequent election victory. ${ }^{193}$

The availability of pre-hire agreenients in agriculture would also encourage a minority union to bring economic pressure agamst an eniployer in an effort to obtain through force what could not be achieved in an election. It is largely because pre-hire agreements are an incentive to strikes and boycotts that the American Farn Bureau Federation, the spokesgroup for agribusiness interests, lias consistently opposed provisions allowing for pre-hire agreements. ${ }^{194}$ Of course, any coitract covering seasonal workers would be a pre-hire agreement to the extent that it was signed before they were liired for a particular liarvest. But the crucial distinction is that the union would have established its majority status during a previous harvest. Because the availability of pre-hire agreenents to minority unions encourages labor disputes and mcreases the danger of collusive agreenents, it would not be wise to apply section $8(\mathrm{f})$ to agriculture. It would be better to make pre-hire agreenents available only to unions that have proven their inajority status.

192. One of the current disputes was actually triggered by a pre-hire agreement between the Teamsters and the lettuce growers, which was signed without regard to the wishes of the workers. Englund v. Chavez, 8 Cal. 3d 572, 578, 504 P.2d 457, 461, 105 Cal. Rptr. 521, 525 (1972).

193. Alaska Salmon Indus., Inc., 90 N.L.R.B. 168 (1950) (election ordered), 94 N.L.R.B. 3 (1951) (results certified).

194. Agricultural Labor Legislation-1969, supra note 4, at 41 (remarks of Robert McMillen, Legislative Representative, UFW), 63 (statement of Charles Shuman, President, American Farm Bureau Federation). 
The new California legislation goes even further than the above proposal by forbidding an employer from recognizing a union on the basis of a card majority. The California Labor Relations Act requires an election as proof of majority status. ${ }^{195}$ This provision nianifests a distrust of authorization cards, in recognition of charges that the Teamsters used forged cards to obtam contracts with the grape growers in 1973.190 But even if those allegations against the Teamsters were true, they do not justify abandonment of the practice of allowing an employer to recognize a union on the basis of a card majority. The NLRA would prove unworkable if an election were required in every bargaining unit. ${ }^{197}$

There is no reason to believe that the risk of dishonesty and forgery is any greater in agriculture. If a union's showing of interest were in fact fraudulent, the grower's recognition of a minority union would constitute an unfair labor practice, since good faith is no defense where an employer recognizes a union without an election. ${ }^{198}$ The marginal increase in the integrity of the process, which would result from liaving an election in every case, simply would not be worth the added expense, and it would be less desirable than allowing growers to recognize a union on the basis of a card majority. Where the employer refused to recognize a union on the basis of a card inajority, however, an election would still be necessary.

\section{b. Recognitional Strikes and Picketing}

A union that has not been recognized by an employer may wish to picket in order to gaim support both among workers and from the public. Or, when a union has the support of a n1ajority of the workers but the employer demes it recoginition, the umon nuay wish to strike or picket, rather than wait for an election, in order to pressure the employer into immediate recognition. Under the NLRA, organizational picketing aimed at generating support among the employees and the public is permitted so long as it does not interfere with the employer's business operations and does not attempt to force the einployer to bargain with the union. ${ }^{199}$

195. CaL. LABor CoDE $§ 1153(f)$ (West Supp. 1976).

196. Interview with Bennett Lincoff, UFW Legal Department, May 1, 1975. A significant proportion of the signatures were allegedly written in the same handwriting.

197. The California Agricultural Labor Relations Board has already spent its entire first year's appropriation, and the legislature has failed to pass an einergency funding ineasure. See note 9 supra. Much of the funds were spent condncting uncontested elections in which the union had obtained an overwhelming majority of the votes cast. Until the Board resumes operation no additional bargaining representatives can be certified, and no bargaining can take place where no union has yet been certified.

198. Ladies' Garnient Workers Union v. NLRB, 366 U.S. 731 (1961).

199. Department \& Speciality Store Employees' Union v. Brown, 284 F.2d 619, 628 (9th Cir. 1960), cert. denied, 366 U.S. 934 (1961). 
On the other hand, picketing that brings economic pressure against an employer im order to extract recognition is strictly regulated by section $8(b)(7)$ of the NLRA. Such recognitional picketing is banned entirely where another umion has been recognized or where there has been a valid election in the preceding 12 months. In other cases, recognitional picketing is only permitted for "a reasonable period of time not to exceed thirty days,"200 after which the union must petition for an election in order to continue picketing. In cases where recognitional picketing is permitted, the employer can obtain an expedited election by filing unfair labor practice charges, ${ }^{201}$ and the election will bar further picketing for 12 months. The 30-day free period is essentially the result of a compromise rather than a reasoned policy judgment, ${ }^{202}$ but its net impact suggests an intent to allow a union 1 month of picketing in which to elicit support from the employees, after which that support must be tested in an election.

Critics of proposals to extend NLRA coverage to agriculture have noted that the Act's 30-day free period would render the ban on recognitional picketing meaningless in the case of a short harvest. ${ }^{208}$ California's recently enacted Agricultural Labor Relations Act bans recognitional picketing entirely, allowing only organizational picketing directed toward informing employees. ${ }^{204}$ But the Califorma act also prohibits an employer from granting recognition without an election, so its ban on recognitional picketing is based on premises not compatible with those underlying the NLRA.

On balance, it is unlikely that a solution as drastic as that offered by the California legislation would be necessary. The NLRA accepts the use of recognitional picketing as a means of inducing an employer to recognize a majority union without resort to election procedures. Moreover, expedited election procedures that could be initiated by either the union or the grower would be a sufficient clieck on prolonged recognitional picketing and strikes. Given the short duration of the harvest, the 30-day free period would be too long; but an exception for agriculture to section $8(\mathrm{~b})(7)$, limiting the period of pre-petition picketing to 7 days, would be reasonable. Finally, if expedited election procedures were not enacted, it would be unfair to deny a union its only means of securing immediate recognition froin the grower. The possible limitation on recognitional picketing in agriculture should be viewed

200. 29 U.S.C. $\$ 158(b)(7)(C)(1973)$.

201. Id.

202. For a discussion of section $8(\mathrm{~b})(7)$, see Dunau, Some Aspects of the Current Interpretations of Section $8(b)(7), 52$ Gвo. L.J. 220 (1964).

203. S. REP. No. 91-83-1969, supra note 34, at 147 (individual views of Mr. Murphy).

204. Cal. Labor CODE $\$ 1154$ (h) (West Supp. 1976). 
as a trade-off for expedited election procedures. If growers wished to be free from recognitional strikes and picketing, they would probably be willing to support provisions for expedited elections. Thus, recognitional strikes and picketing are only legitimate when a union's majority status is clear; elections must be held whenever there is any doubt concerning the workers' true preferences.

\section{Eligibility to Vote \\ a. General Considerations}

The Board requires that before a worker is eligible to vote, lie or she must be employed both on the election date and on some prior ehgibility date set by the regional director at the preelection hearing. ${ }^{205}$ The purpose of this requirement is to allow the umion and employer to electioneer among a fixed group of employees and to avoid confusion on election day. Recently, the Board lias required the employer to provide the union with a hist of eligible voters in order to insure equal access to the electorate during the period between the eligibility date and the election. ${ }^{206}$ The earlier eligibility date also prevents an employer from mampulating the election through massive preelection hiring.

In industries such as longsloring, construction, oil drill rigging and filmmaking, where employment is brief and sporadic, the use of dualdate eligibility would disenfranchise a substantial proportion of the potential electorate. Therefore, the Board lias evolved special ehgibility formulas for those imdustries in order to establish ehigibility for persons who, though not employed on the eligibility date, should be entitled to vote. Generally the Board requires some minimum amount of employment in a previous period as proof that the employee lias a substantial and contimuing interest in the bargaining unit. For instance, in the construction industry the Board extends eligibility to anyone who has worked 30 days in the previous year or 45 days in the 2 preceding years. ${ }^{207}$ On an oil drill rigging crew, all "roughnecks" employed either on the eligibility date or for 10 of the previous 90 days are entitled to vote. ${ }^{208}$ The rule in the film industry is that all employees who worked on at least two productions during the year may vote, even if they worked less than 5 days. ${ }^{209}$ In every case, the employee must be at

205. Statement of Ogden W. Fields, Executive Secretary, NLRB, Agricultural Labor Legislation-1969, supra note 4, at 252. Cf. 29 C.F.R. \& 102.62 (1974), requiring that a similar practice be followed in consent elections.

206. Excelsior Underwear Inc., 156 N.L.R.B. 1236 (1966).

207. Daniel Constr. Co., 133 N.L.R.B. 264 (1961), modified, 167 N.L.R.B. 1078 (1967).

208. NLRB v. Hondo Drilling Co., 428 F.2d 943 (5th Cir. 1970), enforcing 164 N.L.R.B. 416 (1967); NLRB v. Moran Oil Producing Corp., 432 F.2d 746 (10th Cir. 1970), cert. denied, 401 U.S. 941 (1971).

209. American Zoetrope Prod., Inc., 207 N.L.R.B. 621 (1973). 
work on the day of the election, but the formula serves as a substitute for a fixed eligibility date.

In seasonal industries such as food processing, the Board has rarely inade use of general eligibility formulas, adopting instead the rule requiring employment both on an eligibility date and on the date of the election. ${ }^{210}$ The omission of eligibility tests stems from the notion that where seasonal employees have been found to have a substantial interest in the bargaining unit, individual workers need not show that they have worked in previous seasons. The time lapse between the eligibility date and the election allows each employee to acquire a sufficient interest in the election. ${ }^{211}$ The Board insures maximum enfranchisement by setting both the eligibility date and the election during the peak period of production. ${ }^{212}$

If the peak season is far in the future when the Board directs an election, the Board will generally order that the election be held on a date to be determined by the regional director, "among the employees in the appropriate unit who are enployed during the payroll period immediately preceding the date of issuance of notice of election by the Regional Director."213

The Board has often altered this formula and has set the eligibility date as the "payroll period immediately preceding the date of the election." 214 In a inore extreme situation involving salmon fishermen, whose season lasts less than a inonth, the Board dispensed with the eligibility date entirely, ordering an election "among employees in the appropriate unit who are employed on a day to be selected by the Regional Director when a representative nuniber of such persons may be employed. . . ."215

210. Statement of Ogden W. Fields, Executive Secretary, NLRB, Agricultural Labor Legislation-1969, supra note 4, at 252. See, e.g., California Almond Growers Exch., 73 N.L.R.B. 1367, 1372 (1947).

211. Bercut-Richards Packing Co., 68 N.L.R.B. 605, 608 n.6 (1946).

212. Case-Swayne Co., 209 N.L.R.B. 1069 (1974). The California Agricultural Labor Relations Board determined the method by which the peak is to be computed in Mario Saikhon, Inc., 2 A.L.R.B. No. 2 (Jan. 7, 1976).

213. California Vegetable Concentrates, Inc., 137 N.L.R.B. 1779, 1781 (1962); Nephi Processing Plant, Inc., 107 N.L.R.B. 647, 649 (1953); Cain Canning Co., 81 N.L.R.B. 213, 215 (1949).

214. Alaska Salmon Indus., Inc., 78 N.L.R.B. 522, 524 (1948); Fruitvale Canning Co., 78 N.L.R.B. 152, 155 (1948); Liggett \& Meyers Tobacco Co., 74 N.L.R.B. 443, 446 (1947); Greenwich Oyster Co., 73 N.L.R.B. 1459, 1462 (1947); White Pine Lumber Co., 72 N.L.R.B. 1249, 1251 (1947); San Fernando Heights Lemon Ass'n, 72 N.L.R.B. 372, 377 (1947). The California Agricultural Labor Relations Act of 1975, CAL. LABOR CODE $\$ 1157$ (West Supp. 1976), provides that eligibility shall be detcrmined by the payroll immediately preceding the petition.

215. Alaska Salmon Indus., Inc., 94 N.L.R.B. 1211, 1214 (1951). 
The Board's use of dual ehgibility dates would not create special problems in agriculture. If the preelection hearing were held in advance of the harvest-whether on the basis of a petition during the previous harvest or a pre-harvest petition - the regional director would hold the election during the peak of the season, and the eligibility date should be the payroll date preceding the election or any other date selected by the regional director. If expedited election procedures were adopted, the regional director would retain discretion in setting the eligibility date.

Setting the eligibility date only a week before the election would necessitate a departure from the Board's recent practice-allowing an employer 7 days to furrish the eligibility list and then at least 10 additional days before the election is held ${ }^{216}$ - but it is unlikely that such a departure would create substantial problems for either an employer or a union. So long as an employer had advance notice that he must provide a list of all his current employees, even 1 or 2 days would allow sufficient time for compliance. Agricultural unions generally would not be in a position to use the permanent addresses of employees noted on eligibility lists for organizational purposes since they would be soliciting union support in the fields or at temporary labor camps. The major purpose served by the eligibility list in agriculture would be to facilitate the challenging of voters at the polling place. This purpose would be amply served by having the eligibility list available 1 or 2 days before the expedited election.

\section{b. Off-Season Elections}

Although ordinarily an employee must be working on the date of the election in order to vote, the Board has consistently extended eligibility to workers who are temporarily laid-off and retaimed on the employer's seniority list. ${ }^{217}$ The Board has applied this rule even in a seasonal industry, where the lay-offs were an ordinary rather than an extraordimary occurrence. In a case involving a cannery, the Board stated: "[T] $]$ he plant is not now operating. . . . However, all employees are deemed by the company to be only teniporarily laid-off, and, therefore, under the Board's custoniary practice, retain their voting rights." ${ }^{218}$ In later cases involving seasonal industries, the Board did not inquire whether the laid-off employees were retained on the payroll, stating instead that they were "deeined temporarily laid-off" 219 or occu-

216. Note 180 supra.

217. City Auto Stamping Co., 3 N.L.R.B. 306 (1937).

218. Ellis Canning Co., 67 N.L.R.B. 384, 387 (1946).

219. Aspen Skiing Corp., 143 N.L.R.B. 707, 711 (1963). 
pied "a status similar to temporarily laid-off employees."220 Recently, the Fifth Circuit Court of Appeals affirmed a Board decision allowing seasonal employees laid-off by a vegetable processing plant to vote even though the employer had omitted them from the eligibility list. ${ }^{221}$ Thus, it would be possible for the Board to conduct an election among seasonal farmworkers after a harvest in which they had petitioned for an election.

The use of post-season elections would not be desirable in agriculture, however. Unlike canneries, which often draw their workers froin a single nearby town, farms have a work force that scatters after a harvest. Migratory workers often move to other farms. Even when the workers come froin the surrounding area, they are usually day-hauled by a labor contractor and might have difficulty getting to the farm for an off-season vote. The Board lias used mail ballots in recent elections; ${ }^{222}$ but it might be mipossible to send ballots to eligible farmworker-voters, since inany either would liave no permanent address or would be engaged in another harvest away from liome. Furthermore, use of mail ballots presumes a level of hiteracy many farmworkers have not attained. ${ }^{223}$ For these reasons, the theoretical possibility of off-season elections could not be translated into a practical substitute for expedited harvest-time elections.

\section{c. Re-Run and Run-Off Elections}

In cases where a multi-party election proved inconclusive, or where an election was set aside, a second election would be required. Given the short duration of the larvest season, a re-run or run-off election rarely could be held during the same harvest as was the original election, even using expedited election procedures. Since off-season elections would generally not be feasible, the second election would have to be held during the next harvest. A major question in such elections would be voter eligibility.

220. Atlas Imperial Diesel Engine Co., 93 N.L.R.B. 268, 272 (1951).

221. Knapp-Sherrill Co. v. NLRB, 488 F.2d 655 (5th Cir.), cert. denied, 419 U.S. 829 (1974), enforcing 196 N.L.R.B. 1072 (1971). The court stated: "[T]he Board, with the approval of this and other conrts, has held that seasonal employees who are out of work because of a decline in their employer's business but who have a reasonable expectation of reemployment in the future are considered 'temporarily laid off' and eligible to vote in a representation election." Id. at 659-60.

222. E.g., Eck Miller Transp. Corp., 211 N.L.R.B. No. 12 (June 10, 1974); Groendyke Transp., Inc., 154 N.L.R.B. 1040 (1965), remanded on other grounds, 372 F.2d 137 (10th Cir.), cert. denied, 387 U.S. 932 (1967), aff'd on other grounds, 417 F.2d 33 (10th Cir. 1969).

223. S. REP. No. 91-83-1969, supra note 34, at viii (forward by Sen. Harrison Williams). 
Where an election has been set aside and a re-run ordered, the Board practice is to establish a new current eligibility date rather than retain the eligibility date from the original election. ${ }^{224}$ Since it is an entirely new election, the Board apparently feels no obligation to preserve the original electorate. This practice is especially suited to agriculture, where the yearly turnover in einployment is substantial.

In run-off elections, however, Board rules provide that eligibility is limited to employees eligible to vote in the first election and still eligible on the date of the second election. ${ }^{225}$ The courts have uplreld this practice, even though it disenfranchises many employees. ${ }^{228}$ In agriculture this rule would be totally unworkable, since many (if not most) of the workers do not return to the same farm in the following harvest.

The Board lias recognized this problem and does not follow its run-off rule in seasonal industries. In a case involving salmon cannery workers the Board stated that "it would be inequitable and impractical to utilize eligibility lists prepared for use in the original election for a run-off election which cannot be lield until the next season."227 Instead, the Board established an entirely new eligibility list based on employment in the following season. Interestingly, the Board allowed all the original participants to appear on the ballot, ${ }^{228}$ contrary to section 9(c)(3) of the NLRA, which limits the run-off election to the two choices receiving the largest number of votes in the original election. ${ }^{229}$ This departure from the procedure prescribed by the NLRA raises the specter of perpetual run-off elections, no umion proving capable of obtaining a majority. ${ }^{230}$ At present, only two major umions have actively sought to organize farmworkers; and, if the NLRA were to encompass agriculture, the Board would be wise to omit either "no union" or the less popular umion from any run-off election ballots. If seasonal workers had a sufficient interest in the unit to choose a representative for the workers who would be employed in a subsequent harvest, surely their votes could be used to limit the choices available on the run-off ballot in a subsequent harvest. The Board should not feel justified in departing from section 9(c)(3) solely because of the turnover in a seasonal industry.

224. Atlas Imperial Diesel Engine Co., 93 N.L.R.B. 268, 272 n.14 (1951) (dicta).

225. 29 C.F.R. $\$ 102.70$ (b) (1975).

226. NLRB v. Wackenhut Corp., 471 F.2d 761 (6th Cir. 1972); Cone Bros. Contracting Co. v. NLRB, 235 F.2d 37 (5th Cir.), cert. denied, 352 U.S. 916 (1956).

227. Alaska Salmon Indus., Inc., 64 N.L.R.B. 339, 342 (1945).

228. Id.

229. 29 U.S.C. $\$ 159$ (c)(3) (1970).

230. On the facts of the salmon cannery case, however, the procedure followed by the Board seems to have been fair to all parties, because each of the three major unions received approximately one-third of the votes cast. 


\section{d. Strikers and Replacements}

The Board rules governing voting eligibility of strikers and their replacenients could pose difficult problems for an agricultural union contemplating a strike. Section 9(c)(3) of the NLRA provides that economic strikers are eligible to vote in any election conducted within 12 nionths of the commencement of the strike unless they have secured permanent employment elsewhere. ${ }^{231}$ The acceptance by a striking farmworker of coniparable employment at another farm would probably not be construed as "permanent employment," leaving the presumption that the worker would return to the struck farm at the end of the strike. ${ }^{232}$ But a recent ruling by the Board leaves no doubt that beyond the first 12 months of the strike, no strikers will be permitted to vote, ${ }^{288}$ in spite of the fact that they remain "enuployees" under the definition in section $2(3)^{234}$ and continue to be entitled to reinstatement after the strike whenever positions become available. ${ }^{235}$ Strict application of this rule to agriculture would mean that striking farmworkers might only be entitled to vote during the first harvest of the strike, and in no case would they be allowed to vote after the second harvest.

To preserve the eligibility of its members, a striking agricultural union would be forced to send them back to work at the beginning of the following harvest, calling another strike only after the first payroll period. But the growers would not be required to rehire the strikers for the second harvest, because the Board permits employers in seasonal industries to lock out workers and hire temporary replacements whenever bargaining has proceeded to impasse and there is the threat of a strike in the busy season. ${ }^{236}$ In such a situation, the only workers eligible to vote would be those who were strikebreakers in the earlier larvest and who were rehired during the lock out-temporary replacements would not be eligible to vote, ${ }^{237}$ the strikers from the earher harvest would lose their eligibility, because a year would have passed since the commencement of the strike. Hopefully, the Board would not order an election when such a small and unrepresentative percentage

231. 29 U.S.C. $\$ 159$ (c) (3) (1970).

232. See Pacific Tile \& Porcelain Co., 137 N.L.R.B. 1358, 1359 (1962), where the Board held that acceptance of alternative employment, without more, is not evidence of abandonment of the struck job. Such employment does not rebut the presumption that the striker intends to return to his job, and the striker therefore retains his voting eligibility if no proof of abandonment is offered.

233. Wahl Clipper Corp., 195 N.L.R.B. 634 (1972).

234. 29 U.S.C. § 152(3) (1970).

235. Laidlaw Corp., 171 N.L.R.B. 1366 (1968); see also NLRB v. Fleetwood Trailer Co., 389 U.S. 375 (1967).

236. Inter-Collegiate Press v. NLRB, 486 F.2d 837 (8th Cir. 1973), cert. denied, 416 U.S. 938 (1974), enforcing 199 N.I.R.B. 177 (1972).

237. Pacific Tile \& Porcelain Co., 137 N.L.R.B. 1358, 1363 (1962). 
of the work force would be eligible to vote. Because of the possibility that employers might tolerate prolonged strikes in order to enforce their bargaining position-and that farms might, therefore, operate with replacements for extended periods-clarification of the rights of replaced strikers in subsequent elections would be essential. ${ }^{238}$

\section{Election and Contract Bar Rules}

\section{The Election Bar}

Section 9(c) (3) of the NLRA provides that "[n]o election shall be directed in any bargaining unit" in which a valid election has been lield in the preceding 12 months. ${ }^{239}$ If a union loses an election, then the employer is protected for 1 year froin the upheaval of another election. If a union wins an election, the 1-year certification period serves "the dual purpose of encouraging the execution of a collective bargaining contract and enhancing the stability of industrial relations." 240

The commencement of the 1-year period varies, depending on whether a union wins the election. Where no union is selected, the period runs from the date of the balloting. ${ }^{241}$ When a union wins an election, however, the National Labor Relations Board holds that its rights as bargaining representative extend from the date of its certification and not froin the date of the election. ${ }^{242}$ This asymmetry derives from the purposes underlying the rule: where no union is chosen, the employer has a full year free from the nuisance of an election, but where a umon is certified as bargaining representative, that union has a full year $\mathrm{m}$ which to prove its mettle and negotiate a contract free from the challenges of rival unions. The Board extends the certification period in cases where the employer violates section 8 (a) (5) ${ }^{243}$ by refusing to

238. The recent California legislation provides no guidance in this difficult area. CAL. LABOR CODE $\$ 1157$ (West Supp. 1976), simply follows the federal rule that economic strikers who have been permanently replaced retain their voting eligibility for 12 months. The statute does include a special provision that in elections beld during the first 18 months after the legislation is passed, eligibility may be extended to all those who have worked for the employer during the 36 months preceding passage of the statute in order to protect the rights of workers who struck during the 1972 and 1973 harvestsbut this provision will have no significance after 1976. The Califorma Agricultural Labor Relations Board has been engaged in extended hearings to determine the eligibility of 1973 strikers who voted in the first wave of elections in the Fall of 1975 . Although these decisions have been made on a person-by-person basis, some principles of general applicability may emerge froin the process.

239. 29 U.S.C. $\$ 159$ (c) (3) (1970).

240. Centr-O-Cast \& Eng'r Co., 100 N.I.R.B. 1507, 1508 (1952).

241. Retail Store Employees Local 692, 134 N.L.R.B. 686, 688 n.5 (1961).

242. Brooks v. NLRB, 348 U.S. 96, 104 (1954) (holding this rule "within the allowable area of the Board's discretion in carrying out congressional policy").

243. 29 U.S.C. $\$ 8(a)(5)(1970)$. 
bargain with a newly certified union, thereby providing the union a full year of uninterrupted bargaining. ${ }^{244}$ In one case, the Fifth Circuit Court of Appeals enforced a Board order granting a 6-month extension of the certification year where the employer had refused to bargain for an equivalent period..$^{245}$

The Board's election and certification bar would probably present difficulties in agriculture, owing to the short, seasonal nature of employment. Where no union won an election, it night be possible to hold an election during the following season, 1 year later. This would not always be the case, however, because an election near the end of a late harvest in the first year could cause the election bar to extend through an early harvest in the following year, thus postponing another election until the third year.

The arbitrariness of this result would put the Board in a dilemma. To permit elections in successive harvests would, in sone cases, violate the prohibition of section 9(c)(3), which forbids a second election within a 12-month period. On the other hand, a general prohibition of elections in successive harvests would often create a 2-year election bar in agriculture. Given the rapid yearly turnover of agricultural workers, a 2-year election bar would often deny representation to new workers who desired a union. The Board has indicated its intent to avoid creation of a 2-year election bar, in one case entertaining a petition filed during the 12-nonth period in a seasonal industry where the election would not have been conipleted within the 12-nionth period. ${ }^{240}$ In some cases, however, it would not be possible to hold an election more than 12 inonths after the election in a previous harvest; therefore, Congress would have to amend section 9(c)(3) to permit elections in successive harvests in agriculture regardless of the 12 -month rule. ${ }^{247}$

The purpose of a certification bar is to give the prevailing union a year in which to negotiate a contract free from election pressures from rival unions. The certification bar would work well in agriculture so long as the prevailing union was not certified until after the harvest season, in which case the certification year would run through the following harvest, forestalling elections until the third year. Thus, if a union failed to negotiate a contract in the year following its election, it

244. See Mar-Jac Poultry Co., 136 N.L.R.B. 785, 787 (1962).

245. NLRB v. Commerce Co., 328 F.2d 600 (5th Cir.), cert. denied, 379 U.S. 817 (1964), enforcing 140 N.L.R.B. 226 (1962).

246. Alaska Salmon Indus., Inc., 90 N.L.R.B. 168 (1950).

247. It could be argued, on the other hand, that the growers should be protected from elections in consecntive harvests. Whatever inconvenience would be caused by yearly elections would be ontweighed by the interests of farmworkers in selecting a bargaining representative if they so desired. 
would be in a position to strike during the next harvest without fear that permanent replacements would file a decertification petition.

A difficult situation would arise, however, if a union were certified early enough in the harvest that the 12-month bar would not extend through the following harvest. Although rare, such an early certification would threaten the prevailing union with the possibility of an election at the end of the next harvest. If it were unable to negotiate a contract during the harvest in which it was certified, the prevailing union could easily be deterred from striking during the next harvest by the threat of a decertification petition by its replacements. One possible solution would be for the Board to delay certification, thereby insuring that the bar would extend through the subsequent harvest. This procedure, however, would eliminate the possibility for bargaining during the current harvest. Sounder policy would require that the certification year always extend through the harvest following that in which the election was held. Such a rule would assure a prevailing umion one entire harvest season in which to negotiate a contract free from election challenges. Legislative imitiative would be unwarranted, simce the extent of the certification bar is a creation of the Board, and problems in this area would be rare.

In summary, where no union won an election it would not be possible to hold an election in the subsequent harvest, due to the 12month election bar of section 9(c)(3). Congress would have to amend section 9(c)(3) to permit elections in successive larvests where no union won the first election. Where a union prevailed in an election, the certification bar would ordmarily prevent an election in the subsequent harvest. This would be the correct result, and in the few cases where a petition during the subsequent harvest would be timely, it would be proper for the Board to refuse to entertain such petitions. ${ }^{248}$

\section{The Contract Bar}

The current Board rule is that an existing contract bars an election for up to 3 years so long as it meets certain specified criteria. ${ }^{249}$ Since the majority of disputes involve petitions by rival unions near the expiration of the barring contract, the Board has announced special rules governing that period. ${ }^{250}$ The 60 days prior to the termination of a contract (or the termination of the 3-year period for a longer con-

248. The California Agricultural Labor Relations Board will eventually face these issues, since the new California Labor Relations Act contains both the election bar and the certification bar rules followed by the NLRB. See CAL. LABOR Code $\$ \$ 1155.2(b)$, 1156.3(2), 1156.6, 1156.7(d) (West Supp. 1976).

249. General Cable Corp., 139 N.L.R.B. 1123 (1962).

250. Deluxe Metal Furniture Co., 121 N.L.R.B. 995 (1958). 
tract) constitute an "insulated period" in which election petitions are dismissed as untimely. ${ }^{251}$ The 30 days preceding the insulated period are a "free period" in which election petitions may be filed. ${ }^{262}$ Elections take place shortly after the intervening union files a petition, thereby leaving the prevailing union to negotiate with the employer before the expiration of the existing contract. ${ }^{263}$

Application of these rigid guidelines could present serious problems in agriculture, where workers are available to petition only during a 1 or 2 month period. It would be a rare occurrence for the 30-day free period to coincide with the short harvest season, particularly since the contracting parties could time the expiration of the contract so that it fell during the off-season.

The Board has not evolved a consistent policy regarding application of the contract bar to seasonal industries. But the Board has announced that the free period limitation will not apply to seasonal industries: a special seasonal industries rule provides that the current contract does not constitute a bar to a petition concerning representation of employees at the next peak season, when the current contract will not be in force. ${ }^{254}$ Logically, seasonal imdustries should be exempted from the insulated period rule as well. But shortly after announcing these contract bar rules, the Board warned that the 60-day insulated period would be fully applicable in seasonal industries. ${ }^{255}$ Although this caveat was only dictum (and the employment season in that case lasted 5 months), the Board may decide to preserve the final 60 days of a contract for unfettered bargaining even in seasonal industries such as agriculture, where the harvest itself is less than 60 days long.

If the insulated period were applied to agriculture, an incumbent

251. In Deluxe Metal Furniture Co., 121 N.L.R.B. 995, 1001 (1958), the Board explained that a petition filed during the insulated period might create uncertainty during bargaining. For example, einployees might use the thrent of a rival intervening union's petition as leverage to force their current representatives to make unreasonable demands of the employer.

252. Leonard Wholesale Meats, Inc., 136 N.L.R.B. 1000 (1962).

253. Originally, the free period extended for 90 days, beginning 150 days before the contract termination date. But in Leonard Wholesale Meats, Inc., 136 N.L.R.B. 1000 (1962), the Board shortened this to a 30-day period beginning 90 days before the contract ends, noting that new bargaining representatives chosen far in advance of the termination of the existing contract may undermine the existing bargaining relationship. If no petition is filed during the free period, a contract negotiated during the insulated period will again be a bar to petitions. If no contract is agreed to during the insulated period, a petition after the expiration of the contract is timely only if the parties have notice of it or if it is filed 1 day before the parties sign a new agreement. Deluxe Metal Furniture Co., 121 N.L.R.B. 995, 999-1000 (1958).

254. Deluxe Metal Furniture Co., 121 N.L.R.B. 995, 999 n.9 (1958); South Puerto Rico Sugar Co., d/b/a Central Guanica, 100 N.L.R.B. 1309 (1952).

255. Cooperativa Azucarera Los Canos, 122 N.L.R.B. 817 n.2 (1958). 
union and an employer could manipulate the 60-day insulated period to block any petition by an insurgent union. For example, if the harvest occurred during the month of August, an incumbent union and the grower could agree that the 3-year contract should expire on September 15. Since the 60-day insulating period would extend from July 15 through September 15, entirely blanketing the harvest season, the contract bar would pose an almost insuperable barrier to an insurgent union. The most effective solution to this problem would be for the Board to adopt the position of the California Labor Relations Act, which allows a petition and an election at any time during the last 12 months of a contract. ${ }^{256}$ Abandoning the insulated period would cause little or no harm, even if the election disrupted negotiations and the contract expired before a new agreenient was reached. The contract would expire after the harvest, so that the contract vacuum would coincide with a period of little or no employment, leaving sufficient time to negotiate a contract before the next harvest. ${ }^{257}$

\section{E. Alternative Employer Units}

\section{Multi-Employer Units}

Although the discussion thus far has assunied that the bargaining umit would be limited to single farms, elections and bargaining can and do take place in inulti-employer units. Many growers are members of associations organized along geographical and product lines to process and inarket their products. ${ }^{258}$ Occasionally, the NLRB has treated these associations as single units for elections and bargaining. ${ }^{259}$ Growers have followed the same pattern in dealing with the enrerging agricul-

256. CAL. LABOR CODE $\$ 1157.7$ (d) (3) (West Supp. 1976).

257. The rapid yearly turnover in seasonal workers does not suggest that the coutract bar should be shortened to 2 years in agriculture. Although a rapid turnover could lead to frequent change in worker sentiments, it is also true that the existence of agricultural unions could tend to stabilize agricultural employment. For example, by giving a worker seniority according to how long he worked at a given farm, the UFW hiring hall would encourage him to return to the same farm every year. Furthermore, shortening the bar to 2 years would increase the instability of bargaining relationships. If expedited election procedures were unavailable, a petition would have to be filed during the first year of a contract to guarantee an election during the second year. Since among the advantages of extending NLRA coverage are the reductiou of instability and lessening of inter-union rivalies, a 2-year contract bar would be couuterproductive.

258. For a description of the "Sunkist" marketing operation, see Strathmore Dist. Orange Ass'n, 85 N.L.R.B. 1029 (1949). For the suggestion that these associations were originally formed to combat efforts at unionization among farmworkers in the 1930's, see Note, Agricultural Labor Relations-The Other Farm Problem, 14 STAN. L. Rev. 120, 124-25 (1961).

259. See, e.g., Strathmore Dist. Orange Ass'n, 85 N.L.R.B. 1029 (1949); Califorma Almond Growers Exch., 73 N.L.R.B. 1367 (1947); Note, Agricultural Labor Relations-The Other Farm Problem, 14 StAN. L. REv. 120, 143 n.151 (1961). 
tural unions, and contracts have already been negotiated on a multiemployer basis. ${ }^{260}$

There is no multi-employer bargaining provision in the NLRA, but the Board has permitted the formation of multi-employer bargaining umits upon the consent of both the employers and the union. ${ }^{201}$ Various arguments favor multi-employer bargaining: such bargaiming may conserve resources by avoiding repeated bargaining on the same issues; negotiations may be of higher quality when more is at stake; and employers may be assured that they can grant certain concessions without prejudicing their competitive positions.

In many instaurces, mnulti-employer bargaining arises after a union has won separate elections among the employees of each member of an association. Much law lias developed concerning the timeliness of withdrawal from multi-employer bargaining in such cases, ${ }^{202}$ but the immediate concern for purposes of this Article is the question when the multi-employer group constitutes an appropriate unit for purposes of an election. On this issue, much of the Board's case law is not entirely relevant, for it has been developed in the context of a petition by an insurgent union requesting an election among the employees of a single member of an existing multi-employer association. ${ }^{203}$ In holding that the multi-employer unit was the only appropriate unit, and in disnissing the petition of the rival union, the Board was concerned with preserving an existimg unit.

In some respects multi-employer bargaining would be especially suited to agriculture. Seasonal farmworkers do not necessarily return to the same farms year after year, ard the Board might find that they

260. The Western Conference of Teamsters has negotiated a "Western Agriculture Master Agreement" with the Area's Negotiating Committee, representing 120 California companies (primarily lettuce growers). Supplemental "Mixed Vegetable Agreements" covered 170 growers. Agricultural Labor-Management Relations-1973, supra note 14, at 65,74 . An entirely separate agreement was signed between the Teamsters and 31 grape growers comprising the "Coachella Area Negotiating Committee." Id. at 83. For an account of how the Teamsters acquired its lettuce contracts as an outgrowth of negotiations concerning truck drivers and machine operators, see Englund v. Chavez, 8 Cal. 3d 572, 577-81, 504 P.2d 457, 460-63, 105 Cal. Rptr. 521, 524-27 (1972).

261. See 23 NLRB ANN. REP. 36-37 (1958). None of the state agricultural labor acts deal with the question of multi-employer election umits. Although CaL. LABOR CODE $\$ 1140.4$ (c) (West Supp. 1976) includes "any association of persons or cooperation engaged in agriculture" in its definition of einployer, as of January 1976 no election had been held on a multi-employer basis. The 1971 version of the Idaho Agricultural Labor Act, ch. 174, $\S 8(1)$, [1971] Idaho Sess. Laws 832, forbade creation of mnlti-employer units unless all employers consented; but the 1972 reenactment, IDAHO CODE $\$ \S 22-4101-4113$ (Supp. 1975), is silent on the issue.

262. See, e.g., Publishers' Ass'n of New York City v. NLRB, 364 F.2d 293, 295 (2d Cir.), cert. denied, 385 U.S. 971 (1966), and cases cited therein.

263. See, e.g., Wards Cove Packing Co., 160 N.J.R.B. 232 (1966); Alaska Salmon Indus., Inc., 61 N.L.R.B. 1508 (1945). 
lack a sufficient interest in the conditions on any one farm to warrant having a voice in the selection of bargaining representatives. Seasonals could have a greater community of interest with workers in a unit composed of all the nembers of a inulti-grower association. For instance, lettuce workers who returned yearly for the Salinas lettuce harvest might not work for the same farm each year, but they would always work for one of the members of an association composed of all the lettuce growers in the Salinas Valley. The community of interest among farmworkers who were inembers of a multi-grower bargaining unit would consist of more than the statistical fact that they would probably be reemployed each year. Since farmworkers rarely know in advance by which farm they will be hired, their ability to plan and predict would be significantly enhanced by the knowledge that a uniform contract would be in effect at each farm. Furthermore, the Board could more efficiently administer association-wide elections than it could a multitude of elections at individual farms.

In determining whether a multi-employer unit is appropriate, the Board is primarily guided by the following rule: "[A] single-employer unit is presuniptively appropriate and . . . to establish a contested claim for a broader unt a controlling history of collective bargaining on such a basis by the einployers and the union involved inust be shown."264 This rule is suited to multi-employer bargaining by unions that have won separate elections with each employer or that are seeking certification after having bargained without elections, as is often the case in the building trades. ${ }^{265}$ But in agriculture, inulti-einployer bargaining first began around 1970, and in niany instances there has never been bargaining of any kind. If bargaining history were always the determining factor, the Board would rarely approve multi-employer election units in agriculture. The Board's bargaining history requirement only applies to "contested" requests for multi-employer elections, however; the Board does not insist on it if both the einployer and the petitioner seek a multieinployer election and none of the intervening unions seeks to represent smaller units. ${ }^{266}$ Therefore, so long as there were no objections from any of the parties involved, there would be no obstacle to the use of inulti-einployer election units in agriculture.

Under present Board policy, however, a petition by an intervening union for an election on a single farm would autoinatically eliminate that farm from a proposed multi-enployer election unit. The Board is willing to override the claims of intervening unions only when there is a

264. 23 NLRB ANN. ReP. 36 (1958) (footnotes omitted).

265. Note 189 supra.

266. Broward County Launderers \& Cleaners Ass'n, 125 N.L.R.B. 256, 257 (1959); Calumet Contractors Ass'n, 121 N.L.R.B. 80, 81 n.2 (1958). 
history of multi-employer bargaining. ${ }^{287}$ This rule stems from a concern for the rights of employees to "representatives of their own choosing." 268 The union petitioning for a simgle-employer unit will ordimarily have substantial support in that unit but will lack widespread support in the proposed multi-employer unit. The petitioner may be either a relative newcomer in the industry or a small union without the resources for a multi-employer organizing effort. Where 30 percent of an employer's employees express the desire to be represented by a umion other than the one apparently favored by the remainder of a proposed multiemployer unit, the Board will not deny them the opportunity to select their own representative. The scale tips the other direction, however, where a umion seeks to raid an existing multi-employer unit. In this situation, the workers have already had an opportumity to express their wishes. Although their present inclinations may be other than what they once were, due to personnel turnover and changes in individual sentiment, countervailing consideration for the stability of an existing bargaining relationship justifies denying the workers a separate choice.

These considerations would be applicable to agriculture. The absence of substantial bargaining history in agriculture would not imply that the history of multi-employer bargaining should be eliminated as a prerequisite in contested cases. Indeed, if two unions enjoyed support at different farms, it would be unwise to submerge the supporters of either union in large multi-employer units. Rather, it would be proper that the workers at each farm be allowed to express their own preferences. Once representatives had been selected at each farm, the workers could be expected to work only at farms where the umion of their choice had prevailed.

Although multi-employer elections would be rare in the initial unionization of farmworkers, multi-employer bargaining would be potentially significant. Once elections had been held, a umon would be able to bargain jointly with all the growers whose workers it represented in a particular crop or region. If such multi-employer umits continued for several years, the Board would be likely to preserve the unit and deny a decertification petition seeking to limit bargaining to a single farm. At the outset, however, the absence of bargaining history would properly dissuade the Board froin ordering multi-employer elections whenever a union filed a valid intervention petition. ${ }^{260}$

267. See, e.g., Rose Exterminator Co., 143 N.L.R.B. 59 (1963); Alaska Salmon Indus., Inc., 61 N.L.R.B. 1508, 1545 (1945).

268. 29 U.S.C. $\$ 157$ (1970).

269. In its first opinion, the California Agricultural Labor Relations Board concluded that single-employer units were appropriate and declined to order an election in the multi-employer unit requested by the Teamsters in their cross-petition. Eugene Acosta, et al., 1 A.L.R.B. No. 1 (1975). 


\section{The Crew Leader or Labor Contractor as Employer}

Much of the nation's seasonal agricultural labor is supplied by crew leaders or labor contractors who also provide transportation for the workers and often serve as supervisors and payroll agents for the growers. ${ }^{270}$ Section 2(3) of the National Labor Relations Act ${ }^{271}$ excludes supervisors and independent contractors from the definition of employees, so it is unlikely that a crew leader or labor contractor would be considered an employee without the consent of the petitioning union. The crucial question is not whether crew leaders or labor contractors would be considered employees, but whether they should be treated as agents of the growers or as separate employers in their own right. A finding that crew leaders and labor contractors were independent contractors (and, therefore, employers) would insulate growers from statutory obligations under the NLRA with regard to workers procured through crew leaders and labor contractors. Since wages and working conditions are ultimately controlled by decisions of the growers, this result would be undesirable. Also, if a union contract were only enforceable against the crew leader or labor contractor, there could be no grievance against the grower for application of forbidden pesticides or for failure to provide the promised number of jobs.

In determining whether individuals are employees or independent contractors, the Supreine Court has stated that ordinary rules of agency apply. ${ }^{272}$ Presumably, similar principles would apply in determining whether an individual were an independent contractor or a supervisor. The Board uses a "right of control" test to decide whether an individual exercises sufficient freedom of discretion to be considered an independent contractor rather than a supervisor. ${ }^{273}$ But the Board has failed to elaborate on the meaning of this test, stating that "resolution of this determination depends on the facts of each case, and no one factor is dispositive."274

Three cases involving fishermen indicate the vagueness of the Board's "right of control" test. In a 1967 case, the Board purported to apply the test in deciding that rather than being independent contractors, the ship captains on the employer's fishing boats were supervisors of the crewmembers-the crewmembers, in turn, were therefore determined to be employees of the employer, rather than employees of the

270. See text accompanying notes 59,60 supra.

271. 29 U.S.C. \& 152(3) (1970).

272. NLRB v. United Ins. Co., 390 U.S. 254 (1968).

273. NLRB v. Nu-Car Carriers, 189 F.2d 756, 759 (3d Cir. 1951), enforcing 88 N.L.R.B. 75 (1950), cert. denied, 342 U.S. 919 (1952).

274. A. Paladini, Inc., 168 N.L.R.B. 952 (1967). 
captains. $^{275}$ The Board emphasized that the captains took no entrepreneurial risks and were required to sell the entire catch to the employer. The Board found the "captains' control over hiring, firing and internal discipline," their selection of the fishing site and their negotiations with their "employer" over the price of the catch to be irrelevant. ${ }^{276}$ The Board said that the employer controlled the manner and means of their performance, not merely the result sought, so that the captains could not be considered independent contractors. But the Board had to overrule a previous case in which the ship captains had been adjudged independent contractors. ${ }^{277}$ And in an earlier case, involving Alaskan salmon fishermen, the Board upheld an agreement by the union and employers to imclude the ship captains as employees along with their crews. ${ }^{278}$ Such precedent provides little guidance.

Another source of Board precedent involves employment referral services that provide day workers and clerical assistance. In one recent case, the Board ordered an election among the "employees" of an employer operating such a referral service for unskilled labor. ${ }^{270}$ The Board rejected the employer's claims that the workers were casual employees, sliaring little commuxity of interest and not subject to the employer's supervision. The Board noted that the employer "controls the wage rates, the manner in which they are paid, the assignment of work, and, in many cases, the transportation of the laborers to the jobsites."280 Since crew leaders and labor contractors function much like employment referral services, and often supervise their employees as well, this case could be precedent for a Board finding that they, too, are employers under the NLRA. But the employment referral service case could also cut the other way. The Board could not have held that the casual laborers were employees of the customers of the referral service, since they were only employed for 1 day at a time. A finding that the referral service was their employer was the only way in which these casual laborers could obtain union representation. In contrast, the employees of a crew leader or labor contractor usually are sent to farms for more substantial periods of time. The employees of one or several crew leaders or labor contractors could constitute the whole of a bargaiming unit at a single farm, with the grower as the employer.

275. Id.

276. Id. at 953.

277. Frank Alioto Fish Co. \& Boat Seaworthy, 129 N.L.R.B. 27 (1960).

278. Alaska Salmon Indus., Inc., 94 N.L.R.B. 1211 (1951), modified on other grounds, 98 N.L.R.B. 1213 (1952). The Board here distinguished two previous cases in which the captains had been held independent contractors. Alaska Salmon Indus, Inc., 81 N.L.R.B. 1335 (1949); 82 N.L.R.B. 1056 (1949).

279. All-Work, Inc., 193 N.L.R.B. 918 (1971).

280. Id. at 919. 
The only conclusion to be drawn from existing precedent is that in a given case the Board could decide that a crew leader or labor contractor was an employee, a supervisor or an independent contractor, depending both on the facts of the case and the wishes of the parties involved. Inquiry as to how the Board ought to rule on the matter requires consideration of the differences between the roles of the crew leader and the labor contractor.

The migratory crew leader of the Eastern and Central States might, in some cases, be the inost appropriate employer for purposes of collective bargaining. The employees of a given crew leader share a commumity of interest, particularly with regard to wages, transportation, food and shelter, which are provided by or through the crew leader. The workers have a far more enduring interest in the relationship with the crew leader than they have in their relationships with the various growers for whom they work. Moreover, the short duration of the crew's stay at any one farm would make it difficult to treat the grower as the employer and hold an election at each farm-this would be redundant as well as impractical, since the same workers would be voting in each election. In addition, the workers would lose the advantage of having a single bargaining representative and would be represented instead by different local unions as they travelled from state to state. Even if these local unions were part of a single national union, there would be different persomiel in each area and perhaps different contracts as well. Furthermore, the local unions might be less responsive to their transient constituents. It would be inore logical for a crew that remained together to elect its own bargaining representative, drawing upon the local umions for support without depending upon them for representation.

The existence of a migratory bargaining unit could pose certain administrative problems, but none would be imsurunountable. For example, the existing Farm Labor Contractor Registration Act could be of aid in maintaining Board communication with the crew leader and the workers. ${ }^{281}$ Difficulties could arise in the election procedures-as where, for example, a petition was filed im North Carolina and an election was not held until the crew reached New Jersey-but expedited elections would solve this problem. And if the Board has been capable of administering elections among the Alaska salmon fishermen and among cannery workers, it follows that it should be capable of developmg solutions to other administrative problems that would arise in the unit of the crew leader. ${ }^{282}$

281. See generally FLCRA-1973, supra note 47, at 14 (testimony of Ben Robertson, Acting Administrator, Wage-Hour Div., Employment Standards Administration).

282. See note 17 supra. 
The nature of the economic warfare between leader and crew could be unique. A strike is likely to be 100 percent effective when the crew is on the road, away from the contractor's home-base labor supply. But the crew leader may be able to withhold food and shelter, or even abandon the crew in unfamiliar territory. On the other hand, if the crew could select a bargaining representative and choose a bargaining agent or shop steward, the crew leader could become expendable. The crew would have the means of making the necessary arrangements with the local farms. All it would lack would be transportation, and a bus could be procured with union funds. And although the crew members would lack the contacts or experience of the old crew leaders, they could draw on the resources of local unions along their route. The unionization of migratory crews might thus revive the institution of the "protective associations" which originated among Chinese and Japanese farmworkers in California in the 19th century. ${ }^{283}$

Treating the crew leader as an employer would be the exception rather than the rule, and it would generally be limited to the eastern half of the United States, where migratory crews have not given way to dayhaul workers. ${ }^{284}$ Such an arrangement would be inappropriate in California, however, where the dominant institution is the labor contractor. Unlike the crew leader, the labor contractor has no permanent crew, but instead recruits harvest workers for a particular grower. The labor contractor is thus more the agent of the grower and less the employer of individual workers. The workers recruited by a labor contractor share a concern that they are transported safely and paid fairly, but their working conditions are largely determined by the growers for whom they are recruited. The growers who use these labor contractors are primarily large agribusiness concerns. ${ }^{285}$ In contrast to the small farmers who may negotiate with crew leaders, large growers set the wage rate before sending labor contractors to recruit the workers. Furtherinore, workers eniployed by a labor contractor often have hittle more likelihood of reeniployment by a particular labor contractor than they do of reeniployment by a particular grower. Finally, on a given farm there nuay be several contractors whose workers share a community of interest with each other, making the workers of a single labor contractor too sinall a unit for bargaining purposes. The most appropriate bargaining unit on large farms would thus be the workers employed

283. See Seminar on Farm Labor Problems-1971, supra note 3, at 69 (Prof. Pollitt, citing the work of Prof. Jamieson).

284. See FLCRA-1974, supra note 45, at 229-34 (statement of Elijah Boone, Regional Director, Community Action Migrant Program, Immokalee, Fla.).

285. In 1969, for example, 56 percent of contract labor expenditures were by farms with sales of over $\$ 100,000$. See text accompanying note 72 supra. 
by the grower, not the individual labor contractors. The bargaining in California has all been conducted with growers rather than labor contractors.

The NLRB probably would perceive the economic reality when faced with a petition for a farm-wide unit, opposed by a grower claiming that the workers were employees of the labor contractor. In this situation, it is likely that the Board would find a farm-wide unit appropriate. But if workers having a more permanent comection with a crew leader or labor contractor petitioned the Board for a unit in which the employer was the crew leader or labor contractor, the Board should be expected to honor the request.

\section{F. Union Security}

\section{The Union Shop and the Hiring Hall}

The discussion throughout this Article has focused both on workers' rights to choose a representative and on statutory protection of the union's position as collective bargaining agent. To complete the picture, one 1nust consider statutory restrictions on the union's ability to protect its imstitutional well-being through union security arrangements. The union shop is one means of guaranteeing union membership in those states that permit it.

Section 8(a)(3) of the NLRA ${ }^{286}$ prohibits the closed shop but permits a union shop, whereby an agreement inakes umon membership a prerequisite to employment beyond 30 days. NLRA section 14(b), ${ }^{287}$ however, permits states to enact "right-to-work" laws which ban even a union shop. This creates special organizational problems in right-to-work states and has led to a significant controversy over the applicability of section 14(b). ${ }^{288}$

286. 29 U.S.C. $\$ 158(a)$ (3) (1970).

287. 29 U.S.C. $\$ 164$ (b) (1970).

288. Key actors in agricultural labor relations disagree over section $14(\mathrm{~b})$. The UFW insists that any legislation covering farmworkers should exeinpt agriculture froin section $14(\mathrm{~b})$, because other unions were not faced with a similar provision for the first 12 years under the Wagner Act. Agricultural Labor Legislation-1969, supra note 4 at 12 (statement of Dolores Huerta, Vice-President, UFW). The American Farm Bureau opposes the union shop and favors extension of section 14(b) to agriculture in any farm labor legislation. Agricultural Labor-Management Relations-1973, supra note 14, at 150 (prepared statement of Clifford McIntire, Legislative Director, and Matt Triggs, Assistant Legislative Director, American Farm Bureau). The Chairman of the Agricultural Labor Subcommittee of the House Committee on Labor and Education recently referred to section 14(b) as an "atrocity" and predicted that no bill would Icave the committee containing such a provision. Agricultural Labor Legislation-1969, supra note 4, at 152 . 
The availability of some form of union security would be particularly important in agriculture. Because farm labor is generally unskilled, agricultural unions lack that control over the labor market which craft unions maintain through their apprenticeship programs. Moreover, the short duration of seasonal employment at each farm would make it difficult for an agricultural umion to encourage workers to become members. Without a umion shop, as permitted under section $8(a)(3)$, the high mobility and turnover of workers would make it difficult to determine which workers were not union members. The short duration of the work also means the umion would not have the benefit of ongoing pressure by fellow employees on non-jomers.

These problems could be avoided without an exemption from section 14(b), however, if the umion were able to obtain a union hiring hall as part of the collective bargaining agreement. So long as the hiring hall does not discriminate against non-members of the union, the Board allows bargaining agreements to require that all employees be referred by the hiring hall. ${ }^{289} \mathrm{~A}$ hiring hall allows the umion to discover each worker's union status and encourage non-members to join the union. Furthermore, a union is permitted to charge a reasonable fee for use of its hiring hall placement services. ${ }^{290}$ Although this fee will be less than umion dues, the umion has a guaranteed base of funding. Since union dues are probably only shightly more than hiring hall fees, umion membership is encouraged. ${ }^{291}$

Although NLRA section $14(\mathrm{~b})^{202}$ makes it more difficult for a union to acquire members, a strong union with a hiring hall should compete nearly as well as it would with a union shop. Both hiring hall and union shop arrangements exist as the result of bargaining agreements with employers. A union too weak to organize a hiring hall would probably not be able to establish a union shop even if it were legally available. Therefore, the continuing applicability of right-to-

289. Teamsters Local 357 v. NLRB, 365 U.S. 667 (1961).

290. See Local 825, Operating Engineers, 137 N.L.R.B. 1043 (1962), where the Board held that a hiring hall fee for non-union members of $\$ 9$ per month was non-discriminatory relative to $\$ 10$ monthly dues paid by union members. Although $\$ 1.10$ of the dues went to the international, members also paid an initiation fee and paid dues even when not using the hiring hall. But see J.J. Hagerty, Inc., 153 N.L.R.B. 1375 (1965) (only $\$ 6.50$ of the $\$ 10$ monthly dues were attributable to hiring hall expenses, so the Board ordered refund of $\$ 3.50$ from $\$ 10$ hiring hall fee). Thus, the only difference between a right-to-work state and one allowing a union shop may be the difference between the hiring hall fee and the union dues.

291. The hiring hall could be essential to the vital role of agricultural unions in providing the cohesive social structure otherwise lacking in seasonal farm work. To the degree that a union would function as such a social unit, it wonld be capable of attracting and maintaining menbership, particularly given the slight additional cost of joining the hiring hall.

292. 29 U.S.C. $\$ 164(b)(1970)$. 
work laws to the agricultural industry would not be a significant barrier to the emergence of strong agricultural unions.

Even in states where a union shop is legally available, it nnay not have any practical utility. In these states, the proviso to NLRA section $8(a)(3)^{203}$ allows a 30-day grace period before inembership can be required of a new einployee. This would make the union shop virtually worthless in agriculture, where nuch of the work involves less than 30 days' employment at any one farm. The Act currently inakes provision for the similarly sporadic nature of entployment in the building and construction industry. Section $8(f)(2)$ of the NLRA permits union shop agreements in that industry to require membership after only 7 days' employment. Agriculture presents an even stronger case for such a provision, since the labor force is less highly organized and the duration of employment niay be shorter. Any bill including agriculture under the NLRA should provide for a shorter grace period for union shops in agriculture. ${ }^{204}$ Without such an amendment, the availability of a union shop would be of little practical significance, and farmworker unions would have to rely on union hiring halls to inaintain their membership.

As is true of the building trades, hiring halls can lead to de facto closed shops. ${ }^{295}$ Section $8(f)(4)$ of the NLRA, ${ }^{296}$ which permits the union to obtain an agreentent establishing minimunu standards of training and experience, encourages this result. This provision allows the union to require that all employees participate in its apprenticeship

293. 29 U.S.C. $\S 158(a)(3)(1970)$.

294. Several of the bills introduced in recent years have included a 7-day union shop provision. See, e.g., H.R. 1410 \& 2, H.R. 3625 \& 2 and H.R. 5010 tit. I, § 2, 92d Cong., 1st Sess. 1971, collected in Summaries-1972, supra note 85.

295. This fact led the Board to rule in 1957 that an exclusive hiring hall constituted a per se violation of sections $8(\mathrm{~b})(1)(\mathrm{A})$ and $8(\mathrm{~b})(2)$ unless the agreement with the employer contained certain explicit guarantees of non-discrimination. Associated General Contractors, Inc., 119 N.L.R.B. 883 (1957). In 1959, Congress recognized the long history of and reliance upon the hiring hall in the building and construction industry, and in section 8(f)(3) of the Landrun-Griffin Act created an exception permitting use of the hiring hall in that industry. Labor-Management Reporting and Disclosure Act of $1959, \S 8(f)(3), 29$ U.S.C. $\$ 158(f)(3)$ (1970). Then, in a 1961 case, the Supreme Court overruled the 1957 Board decision, holding that although "the very existence of the hiring hall encourages union membership," an exclusive union hiring hall does not violate the NLRA; violations of sections $8(a)(1)$ and (3) and $8(b)(1)(A)$ and (2) can be proved only by evidence of "specific discriminatory practices." Teamsters Local 357 v. NLRB, 365 U.S. 667, 675-76 (1961). The Supreine Court decision thus rendered section $8(f)(3)$ superfluous, since the hiring hall was thereafter lawful in all industries. Even under section $8(f)(3)$ hiring halls in the building and construction industry remain subject to the provisions prohibiting discrimination against non-inembers of the union. See generally Foster \& Strauss, Labor Problems in Construction: A Review, 11 IND. REL. 289, 298 (1972).

296. 29 U.S.C. $\$ 158(f)(4)$ (1970). 
program or an equivalent. Since equivalent training may not be available elsewhere, this requirement may effectively deny einployment to all non-members of the union. Since section $B(f)(4)$ specifically allows preference based on length of service in a particular geographical area, a union may exclude meinbers of other locals of the same union as well as new residents. ${ }^{297}$ Furthermore, qualified individuals who are illegally demied employment usually lack both the resources for an effective challenge and the evidence necessary to prove discrimination.

It is unlikely that hiring halls in agriculture would convert farm labor into a closed shop. Agricultural labor is generally unskilled, so it is less likely that training requirements could be used as a basis for discrimination against non-meunbers of a umion. Since there is no history of closed shops in agriculture, non-nnembers and members would have the same experience. Discrimination based on semiority with the employer, in the industry, or in the area also would be unlikely, because of the inconsistent pattern of reemployinent. Closed shops in the building trades are primarily attributable to apprenticeship programs and to the tradition of closed shops in the industry prior to their coverage under the NLRA. Since neither of these factors is present in agriculture, de facto closed shops would be less likely. ${ }^{208}$

Agricultural umions ought to be able to function without the closed shop. If the grace period were shortened to 7 days-or to 5 , as the California Act provides-the union shop would adequately guarantee union inembership in states that permit the union shop. ${ }^{200}$ In right-towork states and at farms where the umion was unable to obtain a union shop, the hiring hall would be a reasonable substitute. ${ }^{300}$

\section{The Hiring Hall and the Crew Leader/Labor Contractor System}

In theory, the institution of the hiring hall and the crew leader/labor contractor system could coexist. In practice, however, the hiring

297. C. Morris, THe Developing Labor LAW 715 (1971), and cases cited therein.

298. The UFW hiring hall currently operates as a closed shop, union membership being a prerequisite to employment. If covered by the NLRA, the UFW would be forced to open its hiring hall to non-members of the union. An examination of the desirability of the closed shop is beyond the scope of this Article. Regardless of its desirability, however, it is unlikely that Congress would allow the closed shop in agriculture.

299. Short harvests would not prove a bar to permanent union membership. Once a worker had become a member of a union after 7 days at one farm, a reasonable union initiation fee would be sufficient to discourage the worker from quiting the union after each job with the intent of avoiding payment of union dues during the first week at each subsequent farm. As long as subsequent harvests lasted longer than a week, it would be to the worker's advantage to remain in the union.

300. The Teamsters Union has not provided for the use of hiring halls in its recent Califorria contracts. But California allows a union shop clause in the Teamster contracts. It is not certain how the Teamsters Union will respond to the difficulties of 
hall system might replace the labor contractor system ${ }^{301}$ and threaten the role of the crew leader.

Crew leaders would face less of a challenge from the hiring hall than would labor contractors, for their services-provision of continuous transportation, food and shelter over large distances and for long periods of time-would be difficult, though not impossible, ${ }^{302}$ to duplicate. To the extent that local and regional hiring halls would rationalize the labor supply in eacli area by providing employment information (and perhaps transportation), they would hasten the long term transition from reliance upon migratory crews to use of day-haul workers. ${ }^{303}$ And for migrant workers, the network of umion hiring halls would be a functional replacement for the inefficient and hittle-used farm placeinent service maintained by the United States Employment Service pursuant to the Wagner-Peyser Act. ${ }^{304}$

Labor contractors, on the other hand, would face a more immediate threat from the institution of the hiring lrall. The UFW hopes to use its hiring halls to abolish the labor contractor system. ${ }^{305}$ But labor contractors still recruit the workers for farms under Teamster contracts. $^{306}$ The fate of labor contractors under the NLRA would be uncertain and might turn on the outcome of the current conflict between the UFW and the Teamsters. ${ }^{307}$

\section{CONCLUSION}

Because of inadequate state statutes and lack of state administrative experience in labor relations, federal legislation is needed to protect the right of farmworkers to bargain collectively. The NLRB has a wealtl of relevant administrative and technical experience; the exainination of its precedent has demonstrated that extension of NLRA coverage to farmworkers offers a viable alternative to the presently inade-

membership mamtenance if it becomes the representative of farmworkers in a right-towork state.

301. FLCRA-1973, supra note 47, at 85 (George G. Higgins, "The Farm Labor Dispnte").

302. See text accompanying note 283 supra.

303. See text accompanying note 47 supra.

304. 48 Stat. 114 (1933), as amended 29 U.S.C. $\$ 49(b)$ (1970). See Note, $A g$ ricultural Labor Relations-The Other Farm Problem, 14 STAN. L. REv. 120, 134-35 (1961).

305. See note 301 supra.

306. In fact, many labor contractors have signed with the Teamsters so that their workers are covered by Teamster contracts at farms where the grower has not signed with the Teamsters. FLCRA-1973, supra note 47, at 94 (letter to Rep. William Ford from David A. Sweeney, Political and Legislative Director, Teamsters Union, June 15, 1973).

307. See note 300 supra. 
quate state agricultural relations policies. Only a handful of statutory modifications appear to be necessary: an amendment to section 9(c) (1) providing for expedited election procedures; reduction of the maximum duration of recognitional picketing under section $8(\mathrm{~b})(7)(\mathrm{c})$; a proviso to section 9 (c)(3) permitting elections in consecutive harvests if no umion wins an election; and a shorter union shop grace period under section $8(a)(3)$.

There are no "administrative reasons" that justify denial of NLRA coverage to farmworkers. The real obstacles are, as they always have been, political. Once the country's growers and unions have grown accustomed to seeing their economic warfare conducted within a sinilar framework in California, perhaps both sides will be ready for nationwide NLRA coverage. By then, both Congress and the National Labor Relations Board will be able to draw on experience attained under the California Labor Relations Act to formulate more detailed solutions to the technical problems discussed herein, as well as to the others which will undoubtedly arise. 